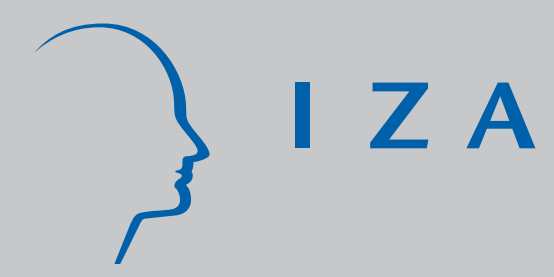

IZADP No. 2762

Do Family Planning Programmes Help Women's Employment? The Case of Indian Mothers

Gianna Claudia Giannelli

Francesca Francavilla

April 2007 


\title{
Do Family Planning Programmes Help Women's Employment? The Case of Indian Mothers
}

\author{
Gianna Claudia Giannelli \\ University of Florence, \\ CHILD and IZA \\ Francesca Francavilla \\ University of Florence
}
Discussion Paper No. 2762
April 2007

IZA

P.O. Box 7240

53072 Bonn

Germany
Phone: +49-228-3894-0
Fax: +49-228-3894-180
E-mail: iza@iza.org

\begin{abstract}
Any opinions expressed here are those of the author(s) and not those of the institute. Research disseminated by IZA may include views on policy, but the institute itself takes no institutional policy positions.

The Institute for the Study of Labor (IZA) in Bonn is a local and virtual international research center and a place of communication between science, politics and business. IZA is an independent nonprofit company supported by Deutsche Post World Net. The center is associated with the University of Bonn and offers a stimulating research environment through its research networks, research support, and visitors and doctoral programs. IZA engages in (i) original and internationally competitive research in all fields of labor economics, (ii) development of policy concepts, and (iii) dissemination of research results and concepts to the interested public.
\end{abstract}

IZA Discussion Papers often represent preliminary work and are circulated to encourage discussion. Citation of such a paper should account for its provisional character. A revised version may be available directly from the author. 


\section{ABSTRACT \\ Do Family Planning Programmes Help Women's Employment? The Case of Indian Mothers}

The paper deals with female employment in developing countries. We set out a model to test our argument that, at the first stage of development, demographic and health programmes have proven to be more effective for women's position in the society than specific labour and income support policies. Our household model in the collective framework predicts that an exogenous improvement in household production technology due to demographic and health policies gives the wife the opportunity to employ her time resources more efficiently, and, by consequence, the power to choose to participate or not to the labour market. A unique, rich and representative data survey for all Indian states and rural India (NFHS-2, 1998-1999) allows us to analyse the role of Family Planning (FP), reproductive and child care programmes, for the employment probability of married women aged 15 to 49 . Our results for urban and rural India show that the FP effect is significant in rural India, that is, women that have been visited by an FP public worker have a higher probability of being employed. Moreover, for rural India, we compare this effect with that one of Governmental Policies (GP) supporting household income and promoting employment. Our results show that the effect of this particular FP intervention has been more effective for women's employment than GP. This result appears to be robust across different definitions of female employment and model specifications.

JEL Classification: J13, J16, J22, O18

Keywords: women's employment in developing countries, family planning, urban and rural analyses

Corresponding author:

Gianna Claudia Giannelli

Dipartimento di Scienze Economiche

Università di Firenze

Polo delle Scienze Sociali

Via delle Pandette 9

50127 Firenze

Italy

E-mail: giannelli@unifi.it

\footnotetext{
* We thank Tindara Addabbo, Maria Laura di Tommaso, Paolo Sestito and the participants to the session on labour markets and globalisation of the $\mathrm{V}^{\text {th }}$ Marco Biagi international conference for useful comments and suggestions.
} 


\section{Introduction}

Much of the literature on female participation to the labour market in developing countries focuses on the conflict between maternal employment and women's family roles. It is argued, in particular for South Asian societies, that women's participation in income generating activities external to the family results in poor health outcomes and higher mortality for the children. Also, in countries where outside labour opportunities for females are poor, the increase in women's schooling is predominantly seen as a pre-condition to improve children's education $^{1}$.

This attention to women's reproductive role and child welfare persistently conflicts with the efforts to promote greater labour market female involvement. The social preference for limiting women's activities to the domestic sphere, however, is often overridden by economic necessity, and poorer women are sometime more likely to be employed than richer women (Desai and Jain, 1994).

By contrast, other studies show that the greater the mothers' control over family resources, the greater their children welfare level. In this approach, an alternative interpretation of the role of schooling, for example, is that mothers with higher levels of schooling have better options outside the household that give them a greater command on family resources which they choose to allocate to children at higher levels than fathers would (Folbre, 1987; Thomas 1990; Haddad Hoddinott and Alderman 1997) ${ }^{2}$. In the 90's, these observations have led the international institutions (World Bank, 1991, United Nations, 1996) to a strong recommendation for increasing women's participation in the market, as a key strategy to reduce fertility and mortality, improve nutrition and welfare.

The policy of liberalisation and opening up of new type of employment opportunities has led only to a marginal increase in female employment in non-agricultural occupations. As far as economic policies are concerned, national programmes in favour of female employment have tended to preserve the women's domestic role promoting occupations in traditional skills, home-based and part-time work. These programmes have not yielded many results in terms of better jobs and earnings opportunities for women (Mehra, 1997; Raikhy and Mehra, 2003).

\footnotetext{
${ }^{1}$ Behrman, Foster, Rosenzweig and Vashishtha (1999), for example, argue that in low income countries the growth in female employment opportunities, which may be difficult to effect via specific programme interventions, is not a necessary condition for achieving greater schooling investment if schooling enhances women's productivity in the home production of human capital.

2 The role of mothers' employment on children development is a hot topic also for developed countries. Many studies show that mothers' full time employment might have detrimental effects on children's cognitive development (see. e.g. Ruhm, 2004; Ermisch, 2004)
} 
Our focus is on the role of demographic and labour market policies for women's employment. We set out a model to test our argument, that is, at the present stage of development, demographic and health programmes have proven to be more effective for women's position in the society than specific labour and educational policies ${ }^{3}$. We concentrate on family planning (FP), reproductive and child-care programmes implemented in India, in particular since 1996, a year of radical transformations in population-related policies. We choose this country because it has a long standing and, by now, consolidated tradition in demographic policies. In order to test our argument, we contrast the effects of these demographic policies with those of governmental programmes for alleviation of poverty in rural India.

The paper is structured as follows. The next section provides a description of women's employment in India on the basis of the NFHS survey data, which we use for our estimation (NFHS-2 for 1998-99). The following two sections review briefly employment and demographic policies implemented in India from the 1950s onwards. Section 5 presents our baseline theoretical model. Section 6 describes our sample and variables. Section 7 discusses our results and section 8 concludes.

\section{Female employment in India: a way towards women's empowerment?}

Our focus is on married women's occupation in the labour market. In our framework, we consider employment as a way towards women's empowerment. This view is closely linked to the idea that women can control resources if they contribute to them, and that earnings from their own work is the easiest resource to control. If labour is assumed to have this function, identifying it in developing countries poses several definitional problems. This is because a great number of women is engaged in agricultural and household activities that are often unpaid, or paid in kind, or paid in cash and kind, and frequently uncounted. A brief description of female employment in India offers a stylised example of this situation.

The female employment rate of Indian women is low compared to that of other developing and developed countries, but shows an increasing trend in recent years. The National Family Health Survey reports that the employment rate of ever-married women for India as a whole was 32 per cent in 1992-1993 and achieved 37 per cent in the years 1998-1999.

\footnotetext{
${ }^{3}$ Mehra (1997), referring to Sen's capability approach writes: “Empirical data show that it has been relatively easier to expand women's capabilities than their opportunities. ... considerable progress has been made in improving women's capabilities in building their human capital through improvements in access to primary education and better health care” (p. 5).
} 
Given the huge geographic dimension and the obvious different opportunities of work throughout the country, it is not surprising that an astonishing difference in women's employment rate exists between Indian states. The highest percentage of women who work is in the North-Eastern States of Manipur (70 per cent), Nagaland (64 per cent), and Arunachal Pradesh (60 per cent), and the lowest is in Punjab (9 per cent) and Haryana (13 per cent). Women's work participation is also relatively low (25 per cent or less) in Assam, Himachal Pradesh, Delhi, Sikkim, Uttar Pradesh, and Kerala. Participation to work of women is relatively high in all the Southern States except Kerala, all the Western States, and Madhya Pradesh.

The distinction between rural and urban areas reveals other sources of heterogeneity. The employment probability is lower in urban areas (26 per cent) with respect to in rural areas (44 per cent), where women mostly work as agricultural employees or self-employed labourers, being often exploited in terms of earnings and working times.

The higher proportion of women's participation in rural areas is due to the fact that, in developing countries such as India, workforce participation is obliged by poverty. The empowering effect of employment, therefore, strongly depends on the type and the quality of work. It is obvious that women who have occasional, seasonal and/or unpaid jobs or that are reduced to slavery in rural plantation are less likely to obtain an empowerment from their work. Agricultural workers (including self-employed and employee) account for about three-quarters of women who work in rural areas. The self-employed in agriculture, who account for about 60 per cent of all agricultural workers in rural areas, are mostly cultivators. Women who work as cultivators in rural areas, support household self-production and are subject to the seasonality of their work. In fact, 86 per cent of them are unpaid workers and four in ten are employed occasionally or seasonally. Agricultural employees are women employed as agricultural labourers, plantation labourers and related workers, or are other farm workers and forestry workers. Of them one woman in ten is unpaid and more than 4 women in ten are engaged only for seasonal or occasional work.

Women in urban areas are involved in more diversified activities: they are specially concentrated in skilled and unskilled manual works, sales, and domestic activities but also in more qualified activities such as nursing, other medical occupations and teaching. In urban areas the percentage of unpaid and occasional workers is lower with respect to the rural areas. One woman in ten is unpaid and two women in ten are engaged only for seasonal or occasional work. However, also in urban areas, even if less representative on the total number of women at work, the category at higher risk of being engaged in an unpaid and/or seasonal work are the 
self-employed women in agriculture followed by sales and manual workers (skilled and unskilled).

The survey information on the power to control monetary resources can be used to give some empirical substance to the hypothesis of the empowering effect of monetary earnings. A first question, posed to all women, is if they are allowed to have some money set aside that they can use as they wish. 59 per cent of all women are allowed to, 61 per cent of women who are currently employed, 66 per cent of women who are currently employed and paid in cash. A weak empowering effect of monetary earnings may be envisaged, even if the question posed is subject to ambiguous interpretations. A clearer picture emerges if we focus on the relation between the form of payment ${ }^{4}$, the contribution of women's earnings to total family earnings and who decides how to spend it. Figure 1 shows who decides how the wife's earnings will be spent by contribution to total family earnings ${ }^{5}$. If we exclude the case of almost no contribution, it is clear that the power to decide autonomously increases with the proportion of wife's earnings on total earnings. From less than half to about half the power to decide autonomously increases together with that of deciding jointly with husbands, and husbands' power to dispose of their wives' earnings declines. From a contribution of more than half to all, wives are more independent in their decisions.

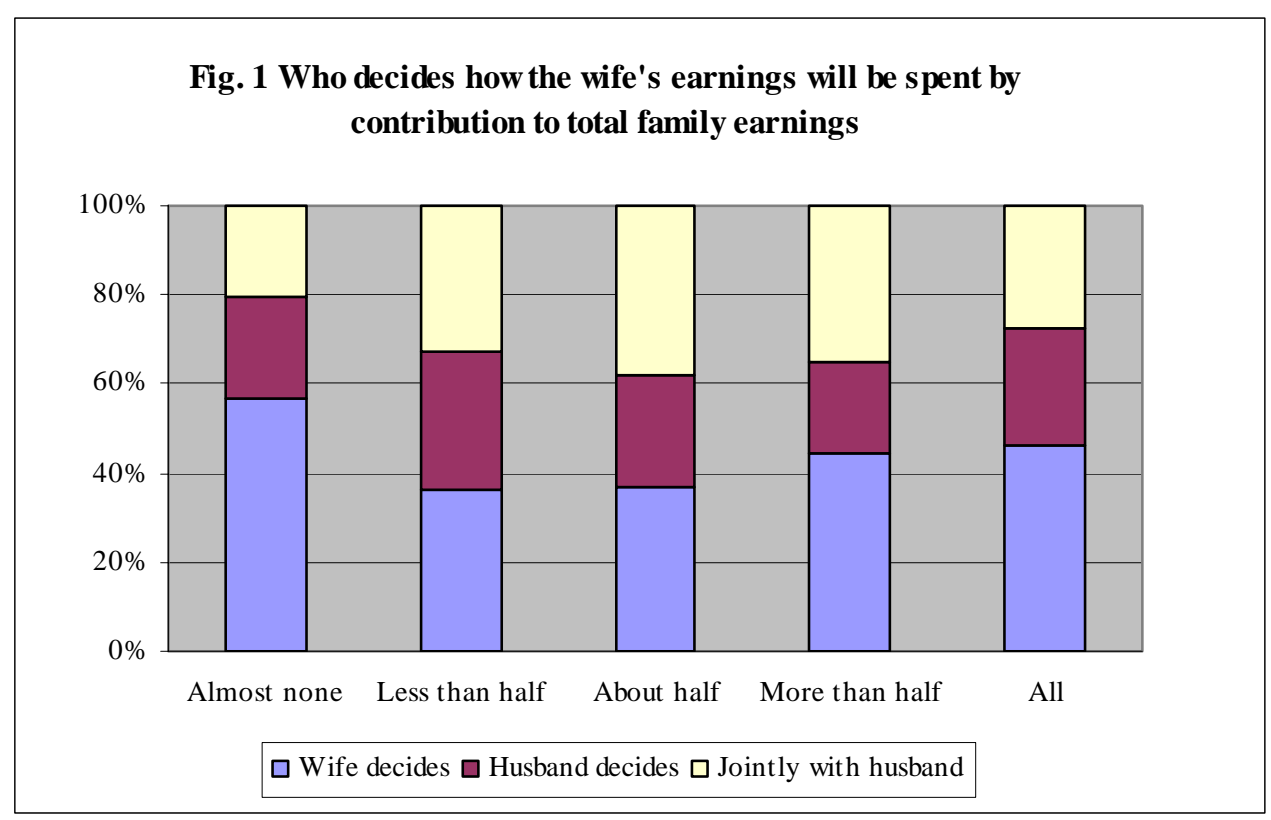

\footnotetext{
${ }^{4}$ As to the form of payment for their work, data drawn from NFHS-2 show that 53 per cent of currently employed married women are paid in cash only. Around 18 per cent are paid in cash and kind or in kind only, and nearly 30 per cent are unpaid.

5 There are other options with low frequencies: “Someone decides” and “Jointly with someone else”.
} 


\section{Governmental Programmes for economic development and}

\section{employment (GP)}

Programmes to easy the access to employment have been implemented in India since the $80 \mathrm{~s}^{6}$. Some of these were specifically addressed to women with the aim of promoting stable and paid occupations. The National Population Policy adopted by the Government of India in 2000 (Ministry of Health and Family Welfare, 2000) explicitly recognized the importance of women's paid employment in achieving the goal of population stabilization and specified measures for paid employment and self-employment. Since women's participation in rural areas is higher, policy makers have traditionally concentrated there their intervention with the objective of improving female work conditions.

Public programmes for economic development aim at alleviating rural poverty through the endowment of productive assets or skills that the poor can employ to increase their labour earnings and thus cross the poverty line. The main one is the Integrated Rural Development Programme (IRDP) started in the 80s. Some of these programmes have a female target. For example, the Development of Women and Children of Rural Areas (DWCRA), a sub-scheme of IRDP started in 1982-83, provides opportunities of self-employment for female members of the rural families below the poverty line ${ }^{7}$. TRYSEM (Training of Rural Youths for Self Employment) is a specifically employment oriented programme under the more general Employment Guarantee Scheme (EGS).

Since 1985-86 two schemes were implemented under the Rural Landless Employment Guarantee Programme (RLEGP): the first one is the Sanjay Gandhi Niradhar Yojana (SGNY), with the objective of providing houses free of cost to the houseless families of rural, hilly and slum areas; the second one is the Indira Awaas Yojana (IAY), with the objective of providing grant for construction of houses to members of Scheduled Castes/Scheduled Tribes, to freed bonded labourers and also to rural poor below the poverty line.

The NFHS-2 collects information on each of these programmes at a village level, recording the number of people in the village who benefited from each one of them in the year preceding the survey. The most widely available rural development programmes, as reported by the

\footnotetext{
${ }^{6}$ For a discussion of employment programmes in India see Mahendra (2006)

7 Another policy relevant for women empowerment is the 1993 amendment to the constitution of India that requires that the States reserve one-third of al1 positions of chief village to women. Chattopadhyay and Duflo, (2004) show that reservation affects policy decisions in ways that seem to better reflect women's preferences. For example, women complain more often than men about drinking water than about roads. In villages headed by women there are more investments in water and less investment in roads.
} 
respondents to the Village Questionnaire, are the IAY and the IRDP. DWCRA, the programme with a female target, covers 23 per cent of total population.

\begin{tabular}{lcc}
\hline \multicolumn{3}{l}{ Table 1: Income support and Labour Market Programmes for Rural Development. } \\
$\begin{array}{l}\text { Percentage of beneficiaries over total de jure popolation } \\
\text { Category }\end{array}$ & Acronyms & Percentage \\
\hline \hline Integrated Rural Development Programme & IRDP & 55.9 \\
Development of Women and Children of Rural Areas & DWCRA & 23.1 \\
Employment Guarantee Scheme & EGS & 9.5 \\
National Rural Employment Programme & NREP & 12.4 \\
Training of Rural Youths for Self Employment & TRYSEM & 8.9 \\
Sanjay Gandhi Niradhar Yojana & SGNY & 11.7 \\
Indira Awas Yojana & IAY & 61.5 \\
\hline Source: NFHS-2, 1998-99 & & \\
\hline
\end{tabular}

\section{The Family Planning programme (FP).}

As to demographic policies, women aged 15 to 49 are the specific target of Family Planning programmes (FP). Even if the main objective of FP programmes is demographic, indirect effects on women's economic conditions through maternal and child health improvements are surely to be expected.

The FP Programme ${ }^{8}$ in India has undergone important changes in recent years and particularly during the 1990s. At the beginning in 1952, it was primarily a clinic-based family planning programme monitoring the family on the basis of family planning targets to achieve a couple participation rate to the health system of 60 percent. After the adoption of the "extension approach” in 1963 and subsequent integrations with the maternal and child health programme, the activities of the programme broadened significantly. In addition to family planning, the programme provided a variety of services to mothers and children, including antenatal, delivery, and postnatal care, immunization of children against various vaccine-preventable diseases, and counselling on maternal and child health problems and nutrition. In the 70s and 80s the FP programme has been accused of using unacceptable methods to induce people to be sterilized and to fulfill administrative targets even after the so called "emergency period" imposed by President Indira Ghandi in 1976-77 (see Saavala, 1999). The central administration gave local health workers targets for the number of women they were to sterilize each month.

\footnotetext{
${ }^{8}$ The actual name is "Family Welfare Program". We rename it FP for expositional purposes, in order to make a clear distinction between demographic and economic welfare policies.
} 
During the years, the emphasis on achieving method-specific targets, particularly sterilization targets, has created a situation in which targets for numbers of acceptors gained precedence over everything else and the programme was not driven by demand.

The International Conference of Population and Development in 1994 in Cairo marked the abolition of the target-oriented approach. The programme was gradually reoriented towards the Reproductive and Child Health Programme that includes components relating to sexually transmitted diseases and reproductive tract infections. After some initial experiments in a few selected districts, in 1996 the "target-free" approach was implemented throughout the country and was renamed the Community Needs Assessment. This approach modified the system of monitoring the programme and made it a demand-driven system in which a worker would assess the needs of the community at the beginning of each year. From then on, FP workers are sent in rural areas to assess the needs of the village communities on the basis of consultations with families, and give advice on a series of problems, not only concerning health (Ministry of Health and Family Welfare, 1998b).

The NFHS includes several questions on the quality of care, of health and family welfare services provided by the public sector and the private sector. The success of FP programmes in our period of analysis is particularly evident in States with demographic and social indicators below the Indian average. Taking as an example one of the most underdeveloped States, Uttar Pradesh, in $2005^{9}$, 53 per cent of women aged 20-24 were married by age 18, an indicator that was equal to 64 percent in 1999. In the same period, the total fertility rate has dropped from 4.06 to 3.82 and the median age at first birth has increased from 18.8 to 19.4 years. The percentage of married women with two living children wanting no more children has risen from 45 to 64. As far as maternal and reproductive health is concerned, antenatal care has increased from 35 to 67 percent of births in the preceding three years, 29 to 64 in rural areas. This fact, together with the increase in institutional deliveries has led to a decrease in infant mortality from 89 to 73 per 1000 births in the past five years.

The FP Programme in India is still being reformed. The recent National Population Policy, released in February 2000, stresses the commitment to reproductive and child health with the statement that "the overriding objective of economic and social development is to improve the quality of lives that people lead, to enhance their well-being, and to provide them with opportunities and choices to become productive assets in society” (Ministry of Health and Family Welfare, 2000).

\footnotetext{
${ }^{9}$ This statistics are drawn from some preliminary reports available for selected States of the new survey NFHS-3 held in 2005-06. The micro-data have not been released yet.
} 


\section{A baseline theoretical model}

We fit our model to the issue of women's empowerment in developing countries. We use a household model with home production, where decision-making is in the hands of two partners $^{10}$. We adopt a "collective approach"11, according to which the two partners have two distinct utility functions, $\mathrm{U}_{\mathrm{i}}($.$) , with \mathrm{i}=1,2$, that they maximize as a weighted average with weights representing the balance of power in the household. Since our focus is on female participation in the labour market, we assume that men always work in the market ${ }^{12}$, the partners consume a bundle of domestic $\left(\mathrm{X}_{\mathrm{d}}\right)$ and market $\left(\mathrm{X}_{\mathrm{m}}\right)$ goods, and the woman has to allocate her time between hours of domestic activities, $H_{d}$, market work, $H_{m}$, and leisure, $L$. We identify domestic work with time spent providing food and preparing meals, preventing and curing diseases of all the family members, and time spent looking after children.

The woman (1) and the man (2) value the two goods in the same way, but the woman has also her leisure L in her utility function. Man's leisure is assumed to be zero. The husband is only indirectly interested in his wife's time, since the household needs to consume at least a minimum level of domestic goods, which he is not able to produce himself being specialized in market labour ${ }^{13}$.

Under these hypotheses the household utility to be maximized is simply:

$$
\operatorname{Max} U=\Theta U_{1}(X, L)+(1-\Theta) U_{2}(X)
$$

where $0<\Theta<1$ is a coefficient that is positively related to the power of the wife ${ }^{14}$.

To begin with, imagine a situation of underdevelopment where women are forced to allocate all their time to domestic work. To give an example, suppose that a couple is not able to control fertility, that health of the household members is at continuous risk, that water and food is difficult to provide and to transform in safe drinks and meals. In one word, home production technology is very poor. As a result, the woman will be overridden by domestic tasks, and all

\footnotetext{
${ }^{10}$ See, for example, Cigno (1991), ch. 2.

${ }^{11}$ See the literature started by Bourguignon and Chiappori (1992). For an extensive survey, see del Boca and Flinn (2005).

${ }^{12}$ This is a realistic assumption. In our sample drawn from NFHS-2, 97\% of husbands work.

${ }^{13}$ Browning and Gortz (2006) call this the "no externalities" assumption, that allows to decentralise any allocation by a redistribution of initial endowments (see p.14). Alternatively, it can be assumed that L enters directly the husband's utility function, like in Basu (2006), if he draws utility from his wife's leisure. Even if this goes beyond the scope of our empirical analysis, we shall return to it later.

${ }^{14}$ Browning and Gortz (2006) call this the "Pareto weight", that may depend on observables such as relative wages and extra-household factors and unobservables such as the degree of caring and personalities of the two partners.
} 
her time will just be sufficient to provide her family and herself the means to survive. The man gives the household a labour income $\mathrm{Y}$, used to buy market goods. We call this period 1.

\section{Period 1: no choice}

In period 1, a woman in the household has no choice over the way she can use her time. She has to produce a given minimum amount of domestic goods, $\mathrm{X}_{\mathrm{d}, \mathrm{min}}$, for her and her family survival. This activity will take all her time $\mathrm{T}$, she will have no alternative, and her power will be null, that is $\Theta=0$. Hence, in the beginning the household preference coincides with the husband's preference. If $X_{d}=f\left(H_{d}\right)$ is the domestic production function, we assume that at time 1 the wife will have to produce survival $X_{d, m i n}=f(T)$. The household will consume also some market goods, that is $\mathrm{X}_{\mathrm{m}}=\mathrm{Y}$ (see Fig. 2).

Suppose the government decides to intervene to improve households' welfare with a family planning policy that sends family planning workers to visit families and give them advice on health, fertility, child care and other related matters. This implies a sudden improvement in domestic technology that gives the woman an opportunity to employ her time resources more efficiently, and, by consequence, a certain degree of control over them. We call this period 2.

Fig. 2 Domestic technology improvement after an exogenous shock:

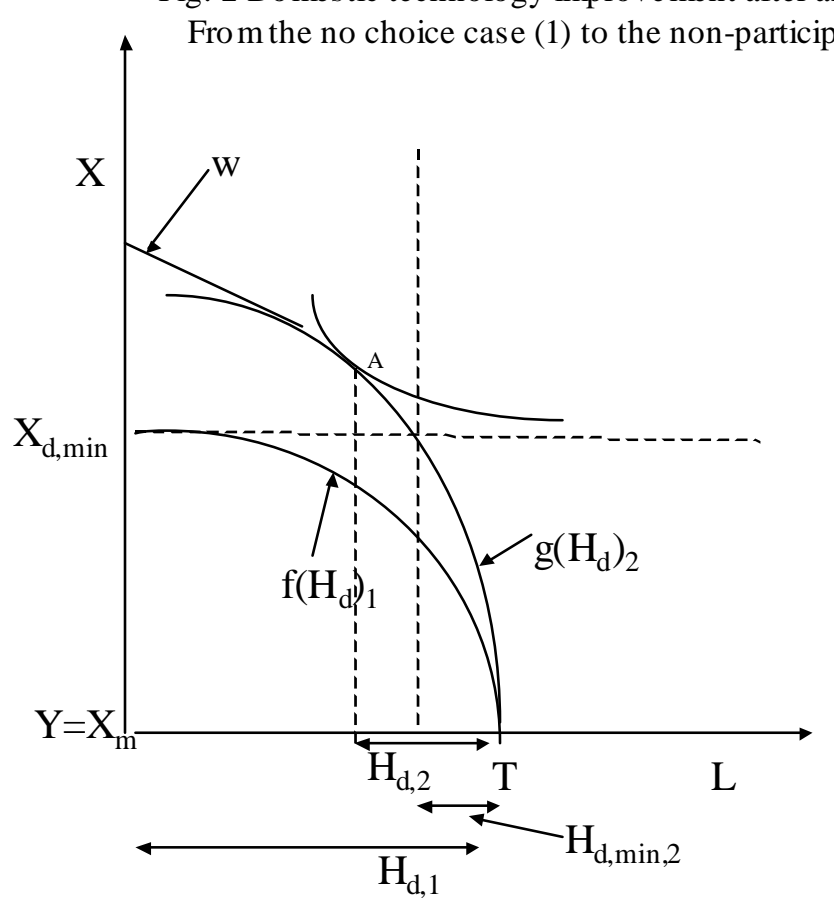




\section{Period 2: the participation decision}

At time 2, after this exogenous shock, the domestic production function becomes $X_{d}=g\left(H_{d}\right)$ with $g^{\prime}\left(H_{d}\right)>f^{\prime}\left(H_{d}\right)$ for all $H_{d}$. At this point, since now producing at least the survival $X_{d, m i n}$ does not involve all her time, we assume that the woman acquires some degrees of freedom over her time allocation, that is

$$
\Theta>0 \text { if } \mathrm{H}_{\mathrm{d}, \min }<\mathrm{H}_{\mathrm{d}}<\mathrm{T} \text {. }
$$

The utility maximization (1) is now subject to the new domestic production function constraint:

$$
X_{d}=g\left(H_{d}\right) ; g^{\prime}>0 ; g^{\prime \prime}<0 ; g^{\prime}\left(H_{d}\right)>f^{\prime}\left(H_{d}\right) \text { for all } H_{d} ; X_{d, \min }=f(T)=g\left(H_{d, m i n}\right) \text {; }
$$

the consumption constraint

$$
\mathrm{X}=\mathrm{X}_{\mathrm{d}}+\mathrm{X}_{\mathrm{m}}
$$

the time constraint

$$
\mathrm{T}=\mathrm{H}_{\mathrm{d}}+\mathrm{H}_{\mathrm{m}}+\mathrm{L} ; \mathrm{H}_{\mathrm{d}, \min }<\mathrm{H}_{\mathrm{d}}<\mathrm{T} \text {; }
$$

and the budget constraint

$$
\mathrm{X}_{\mathrm{m}}=\mathrm{WH}_{\mathrm{m}}+\mathrm{Y} \text {; }
$$

where $H_{m}$ is hours of woman's market work and $\mathrm{W}$ is the real hourly female wage prevailing on the market.

Depending on the woman's tastes and the market wage two situations may occur. Fig. 2 shows the first one, a case of no participation ${ }^{15}$, according to which the woman maximizes her utility specializing in domestic work $\left(\mathrm{H}_{\mathrm{m}}=0\right)^{16}$. The second case is illustrated in Fig.3. In this case, for a given wage, the woman's tastes are such that it becomes convenient to enter the labour market. She will decide to participate and contribute to household income. According to our assumption of women's empowerment through the control of monetary resources, her bargaining power will increase further ${ }^{17}$ thus inducing an increase in $\Theta$.

\footnotetext{
${ }^{15}$ The origin of the y axis of Figures 2 and 3 is rescaled to the amount of market goods that husbands' labour income can buy.

${ }^{16}$ In this case utility maximization occurs at the reservation wage $W_{R}=g^{\prime}\left(H_{d}\right)>W$

${ }^{17}$ Following Basu (2006), the model might be complicated assuming that $\Theta$ is a positive function of $\mathrm{WH}_{\mathrm{m}}$, that is, not just participation, but also the number of hours determine women's decision power in the household. Since our empirical part focuses on the participation decision, this extension to $\Theta$ endogeneity goes beyond the scope of the present paper.
} 
Fig. 3 Domestic technology improvement after an exogenous shock: From the po choice case (1) to the participation decision (2)

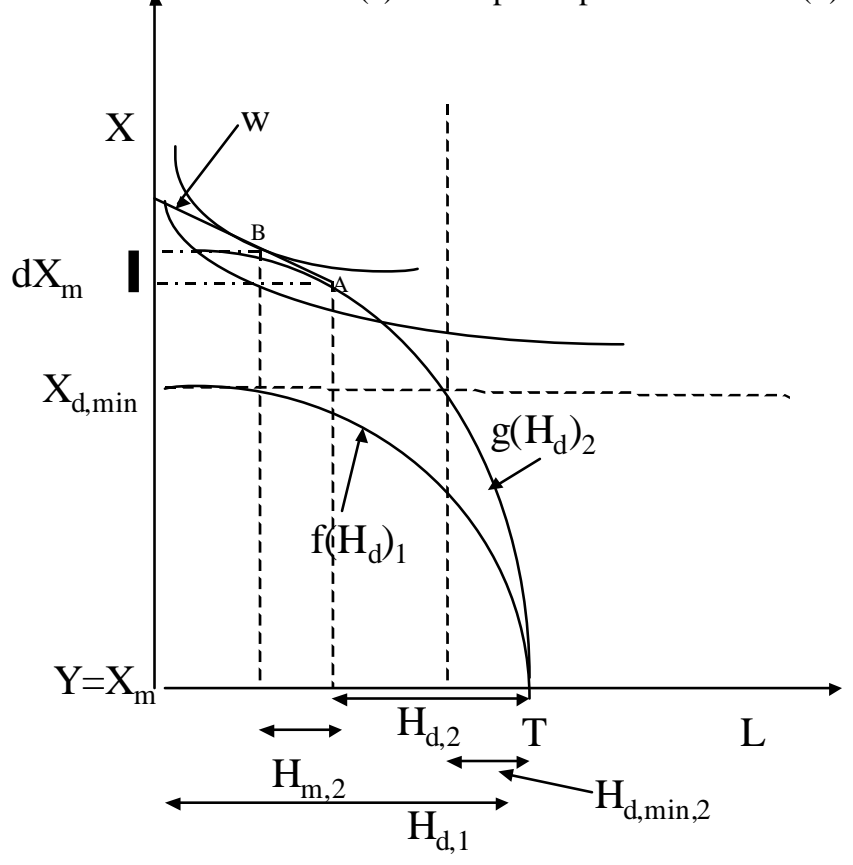

The first order conditions of the maximization of $\mathrm{U}(.)_{1}$ with respect to $\mathrm{H}_{\mathrm{m}}$ and $\mathrm{H}_{\mathrm{d}}$ are:

$$
\frac{U_{L}}{U_{X}}=W
$$

and

$$
\frac{U_{L}}{U_{X}}=g^{\prime}\left(H_{D}\right)
$$

where (6) corresponds to Pareto efficiency in the consumption allocation. From (6) and (7) the equilibrium condition of equality of the marginal product of household production and the wage rate ${ }^{18}$ is derived.

\footnotetext{
${ }^{18}$ Supposing the price of $\mathrm{X}_{\mathrm{m}}$ equals unity, then in monetary terms (6) and (7) yield $w=p^{*} g^{\prime}\left(H_{D}\right)$, that is, in equilibrium, the revenue of an extra hour of domestic work must equal its marginal cost. This relation is useful to impute a price $\mathrm{p}^{*}$ to domestic input in empirical work when time use data are available (see Apps and Rees, 1997).
} 
For empirical purposes, we adopt a static utility comparison framework. In this theoretical context, the woman works if the indirect utility of working for the market is greater than the indirect utility derived from specializing in domestic work. We want to measure how much of the outcome will depend on the exogenous change in domestic technology and in the woman's bargaining power. If the effect will be such to override the threshold given by her reservation wage, she will maximise her utility working outside home.

In other words we assume her indirect utilities to be:

$$
v_{\text {work }}(\mathrm{W}, \mathrm{Y}, \Theta), v_{\text {not work }}(\mathrm{W}, \mathrm{Y}, \Theta)
$$

Since our data do not contain information on wages and incomes, we are compelled to use a reduced form specification. W will depend on the usual set I of individual characteristics of the woman such as age and education, Y will depend on her partner's characteristics $\mathrm{P}$, including education and position in the labour market, $\Theta$ will depend on some indicators of public policies that improve domestic technology and the employment probability (FP and GP). The participation decision will also be affected by other observable household variables $\mathrm{H}$, such as the number and age of children, the household size, and wealth. The above assumptions imply that each indirect utility depends on the following set of variables:

$$
\mathrm{v}=\mathrm{v}(\mathrm{I}, \mathrm{P}, \mathrm{H}, \mathrm{FP}, \mathrm{GP})
$$

In conclusion, to observe a woman working, for example, means that:

$$
\max \left(v_{\text {work }}, v_{\text {not work }}\right)=v^{*} \text { work. }
$$

The empirical part will focus on the following testable predictions that:

1) the participation decision is significantly affected by domestic productivity enhancing demographic policies (FP);

2) the participation decision is significantly affected by employment policies (GP);

3) demographic policies have an impact on the employment probability of women that is at least as large as that of governmental economic programmes. 


\section{Data and variables}

The micro data we use are drawn from the National Health Family Survey ${ }^{19}$, 1998-1999 (NFHS-2). This survey ${ }^{20}$ is designed to provide state and national estimates of fertility, the practice of family planning, infant and child mortality, maternal and child health, and the utilization of health services provided to mothers and children. In addition, the survey provides indicators of the quality of health and family welfare services, women's reproductive health problems, and domestic violence, and includes information on the status of women, education, work and standard of living.

The NFHS-2 is a household survey with a sample size of around 92,500 households and 90,300 ever-married women in the age group 15-49. The sample covers more than 99 percent of India's population living in all 26 Indian states.

The sample size for each state was drawn separately for urban and rural samples proportionally to the size of the state's urban and rural populations ${ }^{21}$. In all states a uniform sample design different for rural and urban areas was adopted. For the creation of the rural sample a two sages procedure was adopted: in the first stage some villages were selected as Primary Sampling Units (PSUs) following a PPS approach (probability to be selected proportional to population size); in the second stage households were randomly selected within each PSU. In urban areas, a three-stage procedure was followed. In the first stage wards were selected with PPS sampling, in the second step from each sample ward one Census Enumeration Block (CEB) was randomly selected, and in the third stage households were randomly selected within each sample CEB. On average, 30 households were initially targeted for selection in each selected enumeration area

NFHS-2 used three types of questionnaires: the Household Questionnaire, the Woman's Questionnaire, and the Village Questionnaire. The Household Questionnaire listed all usual residents in each sample household plus any visitors who stayed in the household the night before the interview. For each listed person in the household, the survey collected basic information on the relationship to the household head and age, sex, marital status, religion, caste/tribe, education, and occupation. The Household Questionnaire also collected information on indicators of household well-being such as the main source of drinking water, type of toilet facility, source of lighting, type of cooking fuel, ownership of house, ownership of agricultural

\footnotetext{
${ }^{19}$ The data are supplied by ORC Macro, Maryland, US.

${ }^{20}$ The first survey was conducted in 1992-93, before the introduction of the FP programme we focus on.

${ }^{21}$ The 1991 Census list of villages served as the sampling frame for rural areas. The 1991 Census list of wards served as the sampling frame for urban areas.
} 
land, ownership of livestock, and ownership of other selected items. In addition, the household questionnaire included very detailed information on household members' health.

Information on age, sex, and marital status of household members was used to identify eligible respondents for the Woman's Questionnaire. Eligible women for the Woman's Questionnaire are defined as all ever-married women aged 15-49 who were usual residents of the sample household or visitors who stayed in the sample household the night before the interview. The Women's Questionnaire collected information on the following topics: background characteristics, reproductive behaviour and intentions, quality of care, sources of family planning, antenatal, delivery, and postpartum care, breastfeeding and reproductive health, knowledge of AIDS. Woman's Questionnaire also investigated on the status of women in the household asking about the treatment of women in the household, gender roles, women's autonomy and violence against women. Questions are also asked about women’s husbands.

The Village Questionnaire collected information from the sarpanch (village head), other village officials, or other knowledgeable person in the village on the availability of various facilities and services in the village (such as health and education facilities, electricity and telephone connections, and others). One important set of questions regarded the distance of the village from various types of facilities including Primary Health Centres, sub centres, hospitals, and dispensaries or clinics and the presence in the villages of services like schools (of different levels) and anganwadi (a nursery school for children age 3-6 years). The Village Questionnaire also collected information about development and welfare programmes operating in the village. Among eligible women we select only married women that amount to a sample of around 85000 observations. This is standard practice in the literature on female participation in the developed world, under the assumption that married women have utility functions and budget constraints different from the no more married and the never married single women, who behave similarly to their male counterpart. The NFHS sample does not include never married single women, but only the no more married group formed by widowed, divorced and deserted women. It is anyway necessary to select them out, since this group is traditionally worlds apart from the married women group ${ }^{22}$. The sample includes married women with and without children, since the latter represent a target of FP visit as potential mothers.

The dataset we construct includes relevant information collected from the Woman Questionnaire supplemented with information at a household level and, for rural India, at a

\footnotetext{
${ }^{22}$ Being no more married is a negative social stigma. In some rural areas of India, it is a common situation that if a husband dies, his widow is considered guilty. In some of the most underdeveloped parts of rural India, if the widow hasn't got a son, the people think that she must die too, because she is useless. The law punishes severely the "Sati", a ferocious ceremony where a widow, usually very young, is burned alive.
} 
village level. The dataset includes, together with women's background characteristics, information on the dimension and composition of the household, on other household's components, including occupation and household wealth ${ }^{23}$. Moreover, our data set contains detailed information on family planning services provided to the household and, at a village level, on the coverage of governmental programmes for economic development of rural areas.

\subsection{Definition of the dependent variable}

In order to contribute to assessing female labour market conditions in developing countries, we construct three variables of female employment probability.

The first one is a binary dependent variable based on the question "Are you currently employed?” We concentrate our analysis on women who are currently employed because we observe that only a low percentage of women (less than 3 per cent, mostly seasonal workers) was working during the year but was not currently working. About 33 per cent of married women is currently employed at the time of interview.

As we assume that the empowerment process speeds up increasing the control over monetary resources, the state of being employed does not necessarily improve women's condition, since a large share of female workers is unpaid. Only 62 per cent of the employed women of our sample are paid in cash, whereas the others are unpaid. Our second dependent variable, therefore, is a multinomial variable with three states, not working, working unpaid and working paid.

A further distinction is related to the duration of work. Permanent jobs are more probably related to women's empowerment. A distinction between “all year” and “occasional” activities is therefore necessary, since a high percentage of employed women (more than 33 per cent) does not work all the year, but is engaged in seasonal or occasional activities. In other words, we divide the better off category of paid workers in those who are engaged in seasonal or occasional activities and those who are employed all year. Thus, the third specification is a

\footnotetext{
${ }^{23}$ The selection of indicator variables to be included in the wealth index is relatively straightforward. Almost all household assets and utility services are to be included, including country-specific items. The reason for using a broad criterion rather than selected items is that the greater the number of indicator variables, the better the distribution of households with fewer households being concentrated on certain index scores. Generally, any item that will reflect economic status is used. Two additional indicators are considered: whether there is a domestic servant and whether the household owns agricultural land. The first is constructed by examining the occupation of interviewed members who are not related to the head of the household. If the respondent or spouse works as a domestic servant and is not related to the head, then the household is considered to have a domestic servant. The second is also based on interviewed members. If any interviewed member (related to the head or not) or interviewed member's spouse works his or her own or his or her family's land, then the household is considered to own agricultural land (Rutstein and Johnson, 2004, p.17).
} 
multinomial variable with four states: no work, work unpaid, seasonal work paid, all year work paid.

Looking at the distinction between urban and rural areas, we observe that the percentage of women at work is higher in rural areas (39 percent against 22 percent). In rural areas it is also more likely to work as unpaid workers or to be paid in kind (56 percent in rural areas against 12 percent in urban areas) and to be employed seasonally (36 percent in rural areas against 22 percent in urban areas).

\subsection{Constructing exogenous FP indicators and comparable GP variables}

Having assessed the relevance of FP in relaxing the burden of women's reproductive and health care roles, we ask whether there is any evidence of a positive impact of these programmes on women's position in the labour market. Using the survey micro data for all Indian States, we focus on the relation between FP programmes and women's employment probability. Information on FP comes form the women's questionnaire.

The survey provides information on many aspects of the FP intervention, like, for example, the use of health facilities. We do not use these demand driven indicators, since they would be endogenous to women's choices. Instead, exploiting the fact that differentials in home visits by background characteristics are generally small, we use, as indicators of the exposition to FP programmes, the passive event of having received at least one visit from an FP worker in the previous twelve months. This indicator should be exogenous to women's choices, depending on the coverage strategy of each State. 13 percent of women aged 15-49 received at least one visit (and, among them, three visits on average ${ }^{24}$ ) which is an impressing result considering the huge Indian population. During these contacts the FP workers monitor various aspects of the health of women and children, provide information related to health and family planning and to the supply of public services, counsel and motivate women to adopt appropriate health and family planning practices. We construct a dummy variable (FPVISIT) which equals one if a women has received a visit in the last 12 months.

Once measured the impact of FPVISIT on the probability of being employed, we then want to compare this effect with that of GP. These variables, recording income support and labour policies, are collected within the village questionnaire, where a village head (sarpanch) is asked about the number of persons in the village receiving a specific benefit. To make the comparison we transform FPVISIT in two new variables. The first one takes value one if a

\footnotetext{
${ }^{24}$ The number of FP visits per woman, instead, might be endogenous if the woman asks the FP worker to visit her again. We therefore do not use this variable.
} 
woman lives in a village where an FP worker has visited at least one woman (even if not herself).

To compare coefficients, we also build a dummy for each welfare programme with the same criterion, that is the programme dummy takes value one if a woman lives in a village where there is at least one beneficiary of the program. The second variable is the ratio of the number of women who received a visit in the village over the total number of people in the village sample. This ratio is based on the sample values representative of the village-universe. For the GP variables we build the ratio of the effective number of people in the village who benefited from each specific programme over the village de jure $e^{25}$ population.

\section{Results}

We estimate logit and multinomial logit specifications of women's employment probability for all States of India, distinguishing between urban and rural India (see the Appendix for the descriptive statistics of all the variables used in the model). For rural India, we also conduct a separate analysis exploiting the additional village information. As we have seen in the data section, for rural India the NFHS provides variables on the number of beneficiaries of a set of governmental programmes whose effects we want to compare with those of FP programmes ${ }^{26}$. We first present our results on the impact on participation of FPVISIT for all India. We then compare the impact of FP with that of GP in rural India.

\subsection{The employment probability and FP}

We start with the impact of FP, and then compare it with that of other control variables that contribute to determine women's participation according to well-established theory and empirical observation. Table 2 reports the marginal effect of FPVISIT on the probability of working of married women aged 15-49 in all Indian States.

\footnotetext{
${ }^{25}$ Residing population.

${ }^{26}$ The NFHS-2 Village Questionnaire collected information from the sarpanch, other village officials, or other knowledgeable persons in the village on facilities and services in the village that can affect health and family planning. One important set of questions focuses on the distance of the village from various types of health facilities, the presence in the village of schooling facilities, including nurseries (angawadi).
} 


\begin{tabular}{|c|c|c|c|c|c|}
\hline \multicolumn{6}{|c|}{ TABLE 2} \\
\hline (margina & $\begin{array}{l}\text { MARG } \\
\text { PROBABILITY C } \\
\text { 0) }\end{array}$ & $\begin{array}{l}\text { AL EFFECTS OF } \\
\text { VORKING OF M }\end{array}$ & DISIT WOMEN A & $5-49$ & \\
\hline & & All India & & & \\
\hline LOGIT & & & & & \\
\hline Depende & $\begin{array}{l}\text { currently working } \\
\text { Marg. Eff. } * 100\end{array}$ & $\begin{array}{l}\text { not working } \\
\text { Observations }\end{array}$ & & & \\
\hline TOTAL & $3.29^{* * *}$ & 82238 & & & \\
\hline URBAN & 1.40 & 25533 & & & \\
\hline$R U R A L$ & $2.57^{* * *}$ & 56705 & & & \\
\hline MULTIN & GIT 1 & & & & \\
\hline & Not working & Working unpaid & Working paid & Observat & \\
\hline TOTAL & $-3.26 * * *$ & $0.55^{*}$ & $2.72^{* * *}$ & 82225 & \\
\hline URBAN & -1.31 & $0.56^{*}$ & 0.75 & 25528 & \\
\hline$R U R A L$ & $-2.42 * * *$ & 0.53 & $1.89^{* * *}$ & 56697 & \\
\hline MULTIN & GIT 2 & & & & \\
\hline & Not working & Working unpaid & & oaid & Observations \\
\hline & & & occasionally & all year & \\
\hline TOTAL & $-0.32 * * *$ & $0.56^{* *}$ & $0.65^{* * *}$ & $1.97^{* * *}$ & 82222 \\
\hline URBAN & -1.21 & $0.57 *$ & $0.67 *$ & -0.03 & 25527 \\
\hline$R U R A L$ & $-2.39 * * *$ & 0.55 & $0.49 *$ & $1.35^{* * *}$ & 56695 \\
\hline $\begin{array}{l}\text { Note: ** } \\
\text { Data sou }\end{array}$ & $\begin{array}{l}p<0.05, * p<0.1 \\
1998-99\end{array}$ & & & & \\
\hline
\end{tabular}

The coefficient is highly significant, and the marginal effect amounts to more than 3 percentage point increase in the probability of being currently employed. The distinction between urban and rural areas reveals that the effect is significant for rural India only ${ }^{27}$. We distinguish, among working women, those paid in cash from those unpaid, since the latter are quite a relevant number as the descriptive analysis has shown. The marginal effects derived from this multinomial logit (see Table 2, Multinomial Logit 1) show that the most significant effect of FPVISIT is to be found on the probability of working paid, that is, an FP contact has a positive impact on the probability of earning own money (about 3 percentage point increase in probability for all India). Again, this is only significant for rural India, where an FPVISIT increases the probability of working paid by about 2 percentage points. A further partition of paid work into occasional (or seasonal) and permanent (all year), demonstrates that the largest impact of FP is to be found on permanent work (see Table 2, Multinomial Logit 2, rural India) that is he best of power enhancing states in our view. Some results concerning the other control

\footnotetext{
${ }^{27}$ This might indicate that urban areas are in a more advanced stage of development. Studies on the impact of liberalization policies in India show that the increase in the GDP rate of growth was concentatrated in urban areas, where also inequality has increased (Cornia, 2004).
} 
variables (see Table 3) are worth commenting for the differences in labour conditions with respect to developed countries (see the Appendix for the complete model specification).

\begin{tabular}{|c|c|c|c|}
\hline $\begin{array}{l}\text { TABLE } 3 \\
\text { MARGINAL EFFECTS OF WOMEN' } \\
\text { (marginal effects*100) }\end{array}$ & TION AI & MILY C & RISTICS \\
\hline & & an States & \\
\hline & TOTAL & URBAN & RURAL \\
\hline Education & & & \\
\hline Womans's years of education & $-4.39 * * *$ & $-2.71 * * *$ & $-4.55^{* * *}$ \\
\hline Womans's years of education sq. & $0.37 * * *$ & $0.26^{* * *}$ & $0.34 * * *$ \\
\hline Children in the household & & & \\
\hline Own children aged 0-2 & $-6.66 * * *$ & $-5.12 * * *$ & $-7.25 * * *$ \\
\hline Own children aged 3-5 & 0.24 & -0.08 & 0.33 \\
\hline Own children aged 6-14 & $1.07 * * *$ & $0.92 * * *$ & $0.94 * * *$ \\
\hline Other children in the family aged $0-2$ & 0.29 & 0.06 & 0.27 \\
\hline Other children in the family aged 3-5 & 0.33 & $2.25^{* * *}$ & -0.39 \\
\hline Other children in the family aged 6-14 & $0.55^{*}$ & $1.07 * *$ & 0.20 \\
\hline Husband's employment position & & & \\
\hline Professional & $-2.00 *$ & $-3.65 * *$ & -0.801 \\
\hline Salesman & $-8.15^{* * *}$ & $-8.40 * * *$ & $-7.54^{* * *}$ \\
\hline Self-employed in agriculture & $3.86^{* * * *}$ & 2.06 & $4.72^{* * *}$ \\
\hline Skilled blue collar & $-5.65^{* * *}$ & $-6.59 * * *$ & $-4.08^{* * *}$ \\
\hline Unskilled blue collar & $-8.39 * * *$ & $-4.45 * * *$ & $-9.40 * * *$ \\
\hline Wealth index & $-10.5^{* * *}$ & $-8.49 * * *$ & $-11.7^{* * *}$ \\
\hline
\end{tabular}

As far as schooling is concerned, female employment is negatively correlated with years of education, with a higher negative effect in rural areas. Mahendra (2004) uses the Household sample of the NFHS-2 survey to study the association of female work participation with the level of schooling. His sample is larger than ours, including all women (married and unmarried, with children and without) aged $15-59^{28}$. The negative relation with schooling is confirmed in rural areas, but he finds a positive, but much less significant, association in urban areas. This result might be due to the presence of young unmarried women without children and older women with adult children. For our sample of married women 15-49 drawn from the Women's sample (therefore less numerous) the association remains negative in urban areas as well, but the marginal effect is lower than in rural areas. This is a major difference with married women participation in developing countries, where education has always been considered as the primary condition to achieve autonomy. Our result rejects this hypothesis for Indian mothers,

\footnotetext{
${ }^{28}$ The author, however, does not control for the presence of children and other household composition variables.
} 
thus suggesting other important roles of mothers' education in Asian societies, such as improving children's welfare and education (Behrman, Foster, Rosenzweig and Vashishtha, 1999). Several studies failed to find evidence of a positive link between women's education and female autonomy, casting doubt on one of the major pathways through which the former was supposed to reduce fertility (see, for example, Jeffery and Basu, 1996, Jeffery and Jeffery, 1996 $)^{29}$. No doubt the role of education for development is fundamental. Various studies have shown the positive effect of maternal education on child health and survival (among these, Dreze and Murthi, 2001). Analyzing data of NFHS-1, 1992-93, Govindasamy and Ramesh (1997) found that mother's education continues to be a powerful, positive and significant predictor of utilization of child health care services in India, even after controlling for a number of other demographic, socioeconomic and spatial variables. Mothers' education is also found to reduce the gender discriminatory practices among mothers of children seeking medical treatment during the post-neonatal and later childhood period (Ghosh, 2004, on NFHS-2).

Turning to the impact of the presence of children in the household, the effect of the number of woman's small children is negative, but only of children up to the age of two; children aged 3 to 5 do not influence their mothers' employment state, whereas older children have a positive impact. The negative effect of small children, however, is relatively small (minus 6 percentage points) as compared to that of FPVISIT (plus 3 percentage points, see Table 2) and to the effect generally emerging from studies on developed countries. The result that children from 3 to 5 do not impede women's work could also be explained by the fact that more than two-thirds of rural residents live in villages that have an anganwadi (a nursery school for children aged 3 to $6)^{30}$. The presence of older children (6-14) has a positive impact on women's occupation (one percentage point increase) since they might offer a substantial contribution to household work. Indian households are often composed by more than one family nucleus. 34 per cent of all households of the survey belong to this category ${ }^{31}$. It is therefore reasonable to ask if the employment status of a woman in a multi-nuclear household depends not only on her own children, but also on other women's children residing in the same household. In order to test for the hypothesis that all children present in the household may have an impact on each residing woman's employment we have introduced some variables measuring the number of children of mothers other than the interviewed. Our test rejects this hypothesis, indicating that only own

\footnotetext{
${ }^{29}$ Dreze and Murthi (2000), however, find strong empirical support to the negative association between education and fertility in India.

${ }^{30}$ See the NFHS report 1998/9, chapter 2 p. 46 and also the next paragraph.

31 Nuclear family households consists of an unmarried adult living alone or a married person or a couple and their unmarried children, if any.
} 
children matter for women's choices. Since only own children 0-2 impede entry into the labour market, the reason is probably to be found in breast-feeding. Nursery services for own children 3 to 5 are therefore not produced within the household by women other than mothers, but most probably purchased in outside nurseries.

Husbands' professional position should capture the effect of partner's income. In fact, all types of husband's employment positions reduce a woman's probability of working, in line with the evidence for many developed countries like the South European ones. Only one husband state has a positive impact, that of a husband self-employed in agriculture, with the obvious implication that wives are involved in the family farm activity.

The coefficient of the wealth index ${ }^{32}$ is negative, large and highly significant, thus confirming the stylised fact that in Asian societies wealthier households keep women at home.

\subsection{Comparing the impact on women's employment of FP with that of GP in rural India}

We now compare the FP effect with that of GP, with a particular attention to policies promoting female employment.

Table 4 and 5 report the marginal effects of FP and of GP on women's employment probability. As explained in the data section, we have constructed two new FP variables for comparison purposes. FPVISIT now has two different meanings: a dummy, taking value one if the woman lives in a village where there has been at least one visit of a FP worker, and a percentage of the number of women visited by FP workers over the total village population. The GP variables are constructed in the same way, so that the coefficients are comparable. The tables report also the marginal effects of the dummies for the presence of nurseries (anganwadi) and primary schools, since these are public facilities relevant for women's employment. It is interesting to note that anganwadi workers not only provide child care services but also engage in the promotion of family planning among parents of preschool age children ${ }^{33}$. The results of the

\footnotetext{
32 According to Filmer and Pritchett (2001) the principal components analysis is used to assign the indicator weights. This procedure first standardizes the indicator variables (calculating z-scores) and then calculates the factor coefficient scores (factor loadings). Finally, for each household, the indicator values are multiplied by the loadings and summed to produce the household's index value. In this process, only the first of the factors produced is used to represent the wealth index. The resulting sum is itself a standardized score with a mean of zero and a standard deviation of one. The wealth index does not produce results that are comparable to either an income-or expenditure-based index since it takes into account almost all household assets and utility services.

${ }^{33}$ That's why we have renamed the variable in Table 4 "Nursery and FP centre". It can not be used with FPVISIT to measure the impact of FP since it might be endogenous to the woman's employment choice.
} 
logit (see Table 4) show that the marginal effect of FPVISIT appears to be relatively high. Taking the dummy measures (col. 1), FPVIST has the larger marginal effect, increasing the probability of employment by 5 percentage points, an even larger effect than that shown in Table 2. This result could be interpreted in this way: a woman that lives in a village where FP workers have made some visits, benefits from positive externalities due to the diffusion of FP information even if she has not been contacted personally. This fact increases he effect of FPVISIT with respect to the variable that took account only of visited women (Table 3).

The presence of facilities for prime age children has the expected positive effect: nursery facilities, increase the employment probability by around 3 percentage points, thus supporting our hypothesis of the outsourcing of child care for pre-school children in rural India. The presence of primary school in the village has also a positive impact, as it is reasonable to expect.

Turning now to the comparison of the impact of FPVISIT with respect to GP, we find that some GP have a positive impact and some other have a negative impact on women's employment (see Table4 col.1). For example, IRDP (Integrated Rural Employment Program) TRYSEM (Training of Rural Youth for Self-Employment), NREP (National Rural Employment Program) have all a negative impact, as if they would support mainly husbands' employment, thus increasing partner's income and generating a negative income effect on participation $^{34}$.

It is probably for this reason that more specific GP for women's employment have been introduced more recently. We find, however, that the effect of one of these, the Development of Women and Children in Rural Areas (DWCRA), is not significant.

To check this result, we use another specification that take in to account the percentage of beneficiaries in the village. Since the FPVISIT variables in col. 2 of Table 4 are continuous, they provide additional information (with respect to the dummy of col. 1) on the dimension of each programme intervention by village. It is therefore reasonable to expect different relative magnitudes and significance of the marginal effects with respect to col. 1. In fact, the marginal effects are no longer larger for FPVISIT and, in particular, the effect of DWCRA becomes significant and larger than that of FPVISIT. Summing up all the GP marginal effects, the total impact amounts to 1.45 , nearly identical to the coefficient of FPVISIT (1.5). This result suggests that the total impact of the various GP on women's employment is just the same as

\footnotetext{
${ }^{34}$ It could also be that if a husband receives a benefit from one programme this makes his wife ineligible for another one. On these aspects, however, we need to investigate further.
} 
that of FP, whose effect should be regarded as operating much more indirectly, through the improvement of domestic production technology.

\begin{tabular}{|c|c|c|}
\hline \multicolumn{3}{|l|}{ TABLE 4} \\
\hline \multicolumn{3}{|c|}{$\begin{array}{l}\text { COMPARING THE EFFECTS OF FP VISIT WITH GP - LOGIT } \\
\text { Dependent variable: work/no work } \\
\text { (marginal effects*100) }\end{array}$} \\
\hline & \multicolumn{2}{|c|}{ Rural India } \\
\hline & Dummies & Beneficiaries \\
\hline & & $\begin{array}{l}\text { (\% of village } \\
\text { population) }\end{array}$ \\
\hline & (col.1) & $(\operatorname{col} .2)$ \\
\hline \multicolumn{3}{|l|}{ Family Planning } \\
\hline FPVISIT & $5.54 * * *$ & $1.50^{* * *}$ \\
\hline \multicolumn{3}{|l|}{ Prime age facilities } \\
\hline Nursery and FP centre & $2.73^{* * *}$ & $2.33^{* * *+}$ \\
\hline Primary school in village & $3.61 * * *$ & $3.87 * * *+$ \\
\hline \multicolumn{3}{|c|}{ GP-Welfare and Labour Market programmes } \\
\hline IRDP & $-1.66^{* *}$ & $-0.80 * * *$ \\
\hline NREP & $-4.66 * * *$ & $-0.71 *$ \\
\hline TRYSEM & $-4.31 * * *$ & $-3.70 * * *$ \\
\hline EGS & $3.26 * * *$ & $2.02^{* * *}$ \\
\hline DWCRA & 0.24 & $2.61^{* * *}$ \\
\hline IAY & 0.54 & 0.40 \\
\hline SGNY & $4.15^{* * *}$ & $1.63^{* * *}$ \\
\hline Observations & 51754 & 51740 \\
\hline
\end{tabular}

The problem is that some GP, supporting household incomes and male employment, have a discouraging effect on women's participation. Specific female oriented employment measures just counterbalance these negative outcomes.

In order to assess the role of the different GP for paid and unpaid work, we estimate the Multinomial logit 1 also for this specification (see Table 5). The specification with the dummies for the presence of beneficiaries in the village confirms that FPVISIT is significant, especially for paid work, and DWCRA is not. The specification with beneficiaries in percentage of village population shows that the effects are very similar for paid and unpaid work both for FPVISIT and DWCRA. So, in this case, the externality effect is on the state of working, independently of monetary payment. 


\begin{tabular}{|c|c|c|c|c|c|c|}
\hline TABLE 5 & & & & & & \\
\hline $\begin{array}{l}\text { COMPARING THE EFFEC' } \\
\text { (marginal effects*100) }\end{array}$ & TS OF FP VISI & $\begin{array}{r}\text { T WITH GP } \\
\text { Rur }\end{array}$ & $\begin{array}{l}\text { MULTINOMIA } \\
\text { India }\end{array}$ & L LOGIT & & \\
\hline MULTINOMIAL LOGIT 1 & & & & & & \\
\hline Type of FP and GP var.: & & Dummies & & Beneficiaries & o of village & pulation) \\
\hline Dependent variable states: & Not working & $\begin{array}{l}\text { Working } \\
\text { unpaid }\end{array}$ & Working paid & Not working & $\begin{array}{l}\text { Working } \\
\text { unpaid }\end{array}$ & $\begin{array}{l}\text { Working } \\
\text { paid }\end{array}$ \\
\hline Family Planning & & & & & & \\
\hline FPVISIT & $-5.26 * * *$ & 0.38 & $4.88^{* * *}$ & $-1.41 * * *$ & $0.74^{* * *}$ & $0.67 * * *$ \\
\hline Prime age facilities & & & & & & \\
\hline Nursery and FP centre+ & $-2.47 * * *$ & $0.92 * *$ & $1.55^{* * *}$ & $-2.18^{* * *}$ & 0.40 & $1.78^{* * *}$ \\
\hline Primary school in village + & $-3.45^{* * *}$ & -0.24 & $3.69 * * *$ & $-3.67 * * *$ & -0.36 & $4.02^{* * *}$ \\
\hline $\begin{array}{l}\text { GP -Welfare and Labour Ma } \\
\text { programmes }\end{array}$ & rket & & & & & \\
\hline IRDP & $1.30^{* *}$ & $-1.82 * * *$ & 0.52 & $0.69 * * *$ & $-0.83 * * *$ & 0.14 \\
\hline NREP & $4.37 * * *$ & $-3.09 * * *$ & $-1.27 * *$ & $0.58^{*}$ & -0.21 & -0.365 \\
\hline TRYSEM & $4.22 * * *$ & $-2.82 * * *$ & $-1.40 * * *$ & $3.63 * * *$ & $-1.60 * * *$ & $-2.03 * * *$ \\
\hline EGS & $-3.32 * * *$ & $2.26 * * *$ & 1.05 & $-1.87 * * *$ & $0.97 * * *$ & $0.90^{* * *}$ \\
\hline DWCRA & -0.13 & -0.46 & 0.59 & $-2.36 * * *$ & $1.47^{* * *}$ & $0.89 * * *$ \\
\hline IAY & -0.51 & 0.44 & 0.07 & -0.37 & 0.05 & $0.31 *$ \\
\hline SGNY & $-4.04 * * *$ & $1.58^{* *}$ & $2.47 * * *$ & $-1.56 * * *$ & $0.58 * *$ & $0.98^{* * *}$ \\
\hline Observations & & 51746 & & 51732 & & \\
\hline
\end{tabular}




\section{CONCLUSIONS}

Our results support the hypothesis that an exogenous improvement in household production technology through demographic and health policies has empowering effects on women's condition in developing countries. In the first stage of development this improvement is at least as important for women as that of economic policies sustaining household income and employment. Our household model in the collective framework predicts that an exogenous improvement in household production technology gives the wife the opportunity to employ her time resources more efficiently, and, by consequence, the power to choose to participate or not to the labour market. If she chooses to participate in paid work, her decision power in the household will increase further.

Our econometric evidence for India does not reject this hypothesis, showing a positive impact of an exogenous FP scheme (the family planning worker visit) on women's employment probability. Coherently with the hypothesis that the model fits a primitive stage of development, the effect is significant only for rural India, indicating that in urban areas the technological improvement in household production has already produced its effects. As to the empowering feedback of demographic measures, our results show that the largest positive impact of FP in rural India is to be found on permanent paid work, as opposed to occasional and unpaid work.

The FP effect is robust to the introduction of income and labour market programmes (GP), some of them directly targeted to reduce women's vulnerability problem. Moreover, the comparison between these programmes shows that their total impact on women's employment probability in rural India is just the same as that of FP. The problem is that some GP, supporting household incomes and male employment, have a discouraging effect on women's participation. We find that more specifically female oriented employment measures just counterbalance these negative outcomes.

If we believe that women's empowerment is closely related to the earning capacity stemming from a permanent paid job, the contribution of FP programmes has to be regarded as a successful, albeit indirect, intervention in this direction. As to public income support and employment policies, they must be carefully studied with an eye to intra-household dynamics, in order to avoid disincentive effects on female participation that could counterbalance the positive effects of specific measures for female employment. 


\section{References}

Apps P. F., R. Rees, (1997), “Collective Labor Supply and Household Production”, The Journal of Political Economy, Vol. 105, No. 1, pp. 178-190

Basu, K. (2006), "Gender and Say: A Model of Household Behaviour with Endogenously Determined Balance of Power”, Economic Journal 116, 558-580

Behrman J.R., Foster A. D., Rosenzweig, Vashishtha P. (1999), "Women Schooling, Home Teaching and Economic Growth”, The Journal of Political Economy, Vol. 107, N0 4, 682-714

Bourguignon, F. and P.A. Chiappori (1992), "Collective Models of Household Behavior: An Introduction”, European Economic Review 36, pp. 355-364

Browning M., M. Gørtz (2006), "Spending Time and Money within the Household”, University of Oxford, Department of Economics, Discussion Paper Series, n. 288

Chattopadhyay R. and E. Duflo (2004), “Women as Policy Makers: Evidence from a Randomized Policy Experiment in India”, Econometrica, Vol. 72, No. 5. pp. 1409-1443.

Cigno S. (1991), Economics of the Family, Clarendon Press, Oxford

Cornia G. A (2004), "Changes in the Distribution of Income over the Last two Decades: Extent, Sources and Possible Causes”, Rivista Italiana degli Economisti n 1.

Del Boca D.,. Flinn C. J, (2005) "Modes of Spousal Interaction and the Labor Market Environment”, ChilD Working Paper n. 12

Desai S., Jain D. (1994), "Maternal Employment and Changes in Family Dynamics: the Social context of women's work in rural India”, Population and Development Review, 115-136

Dreze J., M. Murthi (2001), "Fertility, Education and Development: Evidence for India” Population and Development Review, 27(1): 33-64

Ermisch J., M. Francesconi (2004), “The Effect of Parents' Employment on Children's Educational Attainment”, ISER WP, University of Essex

Filmer, D. , L. Pritchett (2001), "Estimating wealth effects without expenditure data—or tears: An application to educational enrollments in states of India”, Demography 38(1):115-132.

Folbre N. R. (1984), "Market Opportunities, Genetic Endowments and Intrafamily resource Distribution”, American Economic Review, 518-20

Ghosh S. (2004), "Gender Differences in Treatment-seeking behaviour during Common Childhood Illnesses in India: Does Maternal Education Matter?”, 18th European Conference on Modern South Asian Studies University of Lund, Sweden.

Govindaswamy P., B.M. Ramesh (1997), "Maternal education and the utilization of maternal and child health services in India”, National family Health survey Subject Report, No.5, Mumbai, International Institute for Population Sciences 
Haddad L., Hoddinott J., Alderman H. (1997), "Intrahousehold Resource Allocation in Developing Countries”, John Hopkins U.P.

Jeffery, R., A. Basu (eds.), (1996), Girls’ Schooling, Women's Autonomy, and Fertility Change in South Asia (New Delhi: Sage).

Jeffery, P and R Jeffery (1996), "What's the Benefit of Being Educated: Women's autonomy and Fertility Outcomes in Bijnor”, in Jeffery and Basu (1996).

Mahendra S., (2004), "Female Work Participation and Child Labour: Occupational Data From NFHS”, Economic and Political Weekly, February 14, pp. 736-744

Mahendra S., (2006), "Policies and Programmes for Employment”, Economic and Political Weekly, April 22, pp. 1511-1516

Mehra R., (1997), “Women, Empowerment, and Economic Development”, Annals of the American Academy of Political and Social Science, Vol. 554, pp. 136-149.

Raikhy P. S., A. Mehra, (2003) "Changing Structure of Female Workforce in India: An Interstate Analysis”, Indian Journal of Labour Economics 46(4), pp.999-1008

Ruhm C. J., (2004), "Parental Employment and Child Cognitive Development”, Journal of Human Resources, 155-192

Rutstein S.H., Johnson K. (2004), “DHS Comparative Reports No. 6: The DHS Wealth Index”, ORC Macro Calverton, Maryland USA

Saavala M., (1999), "Understanding the Prevalence of Female Sterilization in Rural India”, Studies in Family Planning, 30(4), pp.288-301

United Nations Development Program (1996), Human Development Report 1996

World Bank (1991), World Development Report, OUP 
Table A1

All India summary statistics for the sub sample of married women aged 15-49

\begin{tabular}{|c|c|c|c|c|c|}
\hline Variables & Obs. & Mean & Std. Dev. & Min & Max \\
\hline \multicolumn{6}{|l|}{ Household's characteristics } \\
\hline Woman is the household head & 84862 & 0.02 & 0.14 & 0 & 1 \\
\hline Age of the household head & 84844 & 45.52 & 13.54 & 2 & 95 \\
\hline Household size & 84862 & 6.82 & 3.63 & 1 & 46 \\
\hline Wealth index & 84862 & 0.02 & 1.00 & -1.53 & 2.79 \\
\hline \multicolumn{6}{|l|}{ Children in the household } \\
\hline Own children aged 0-2 & 84408 & 0.36 & 0.55 & 0 & 4 \\
\hline Own children aged 3-5 & 84408 & 0.38 & 0.59 & 0 & 6 \\
\hline Own children aged 6-14 & 84408 & 1.05 & 1.21 & 0 & 7 \\
\hline Own children aged 15-17 & 84408 & 0.25 & 0.50 & 0 & 4 \\
\hline Other children in the family aged $0-2$ & 84408 & 0.19 & 0.51 & 0 & 6 \\
\hline Other children in the family aged 3-5 & 84408 & 0.16 & 0.50 & 0 & 7 \\
\hline Other children in the family aged 6-14 & 84408 & 0.39 & 0.99 & 0 & 16 \\
\hline Other children in the family aged $15-17$ & 84408 & 0.17 & 0.47 & 0 & 5 \\
\hline \multicolumn{6}{|l|}{ Woman's characteristics } \\
\hline Woman's age & 84862 & 31.03 & 8.63 & 15 & 49 \\
\hline Woman's age sq. & 84862 & 1037.46 & 559.31 & 225 & 2401 \\
\hline Womans's years of education & 84825 & 3.99 & 4.76 & 0 & 22 \\
\hline Womans's years of education sq. & 84825 & 38.55 & 61.24 & 0 & 484 \\
\hline Woman is Muslim & 84657 & 0.12 & 0.32 & 0 & 1 \\
\hline Woman is Christian & 84657 & 0.05 & 0.23 & 0 & 1 \\
\hline Woman is in a scheduled caste & 84255 & 0.17 & 0.38 & 0 & 1 \\
\hline Woman is in a scheduled tribe & 84255 & 0.12 & 0.32 & 0 & 1 \\
\hline Woman is currently working & 84847 & 0.3 & 0.5 & 0.0 & 1.0 \\
\hline Woman is currently working as paid worker & 84834 & 0.5 & 0.8 & 0.0 & 2.0 \\
\hline Women is currently working in a seasonal work & 84831 & 0.7 & 1.1 & 0.0 & 3.0 \\
\hline \multicolumn{6}{|l|}{ Husband 's characteristics } \\
\hline Husband's age & 84555 & 36.97 & 9.82 & 15 & 97 \\
\hline Husband's age sq. & 84555 & 1463.42 & 781.20 & 225 & 9409 \\
\hline Husband's years of education & 84693 & 6.58 & 5.08 & 0 & 30 \\
\hline Husband years of education sq. & 84693 & 69.06 & 75.32 & 0 & 900 \\
\hline \multicolumn{6}{|l|}{ Husband's employment position (base cat. No work) } \\
\hline Professional & 83981 & 0.13 & 0.34 & 0 & 1 \\
\hline Salesman & 83981 & 0.11 & 0.31 & 0 & 1 \\
\hline Self-employed in agriculture & 83981 & 0.36 & 0.48 & 0 & 1 \\
\hline Skilled blue collar & 83981 & 0.22 & 0.41 & 0 & 1 \\
\hline Unskilled blue collar & 83981 & 0.10 & 0.30 & 0 & 1 \\
\hline Other position & 83981 & 0.05 & 0.22 & 0 & 1 \\
\hline \multicolumn{6}{|l|}{ Geographic characteristics (base cat. South) } \\
\hline Urban area & 84862 & 0.31 & 0.46 & 0 & 1 \\
\hline North & 84862 & 0.23 & 0.42 & 0 & 1 \\
\hline Central & 84862 & 0.18 & 0.39 & 0 & 1 \\
\hline East & 84862 & 0.18 & 0.38 & 0 & 1 \\
\hline Northeast & 84862 & 0.12 & 0.32 & 0 & 1 \\
\hline West & 84862 & 0.11 & 0.32 & 0 & 1 \\
\hline \multicolumn{6}{|l|}{ Programmes } \\
\hline Woman received a FP worker visit & 84860 & 0.11 & 0.31 & 0 & 1 \\
\hline
\end{tabular}


Table A2

Urban India summary statistics for the sub sample of married women aged 15-45

\begin{tabular}{|c|c|c|c|c|c|}
\hline Variables & Obs. & Mean & Std. Dev. & Min & Max \\
\hline \multicolumn{6}{|l|}{ Household's characteristics } \\
\hline Woman is the household head & 26308 & 0.02 & 0.12 & 0 & 1 \\
\hline Age of the household head & 26301 & 45.61 & 12.92 & 16 & 95 \\
\hline Household size & 26308 & 6.39 & 3.38 & 1 & 41 \\
\hline Wealth index & 26308 & 0.90 & 0.91 & -1.42 & 2.79 \\
\hline \multicolumn{6}{|l|}{ Children in the household } \\
\hline Own children aged 0-2 & 26188 & 0.31 & 0.53 & 0 & 4 \\
\hline Own children aged 3-5 & 26188 & 0.32 & 0.55 & 0 & 4 \\
\hline Own children aged 6-14 & 26188 & 0.97 & 1.15 & 0 & 7 \\
\hline Own children aged 15-17 & 26188 & 0.26 & 0.53 & 0 & 3 \\
\hline Other children in the family aged $0-2$ & 26188 & 0.14 & 0.45 & 0 & 5 \\
\hline Other children in the family aged 3-5 & 26188 & 0.12 & 0.43 & 0 & 6 \\
\hline Other children in the family aged 6-14 & 26188 & 0.30 & 0.87 & 0 & 13 \\
\hline Other children in the family aged $15-17$ & 26188 & 0.13 & 0.41 & 0 & 5 \\
\hline \multicolumn{6}{|l|}{ Woman's characteristics } \\
\hline Woman's age & 26308 & 32.26 & 8.31 & 15 & 49 \\
\hline Waman's age sq. & 26308 & 1109.63 & 551.75 & 225 & 2401 \\
\hline Womans's years of education & 26291 & 6.82 & 5.26 & 0 & 22 \\
\hline Womans's years of education sq. & 26291 & 74.18 & 79.48 & 0 & 484 \\
\hline Woman is Muslim & 26267 & 0.15 & 0.36 & 0 & 1 \\
\hline Woman is Christian & 26267 & 0.06 & 0.24 & 0 & 1 \\
\hline Woman is in a scheduled caste & 26205 & 0.14 & 0.35 & 0 & 1 \\
\hline Woman is in a scheduled tribe & 26205 & 0.06 & 0.24 & 0 & 1 \\
\hline Woman is currently working & 26304 & 0.22 & 0.42 & 0 & 1 \\
\hline Woman is currently working as paid worker & 26299 & 0.42 & 0.80 & 0 & 2 \\
\hline Women is currently working in a seasonal work & 26298 & 0.58 & 1.13 & 0 & 3 \\
\hline \multicolumn{6}{|l|}{ Husband 's characteristics } \\
\hline Husband's age & 26274 & 38.03 & 9.37 & 15 & 95 \\
\hline Husband's age sq. & 26274 & 1534.40 & 756.80 & 225 & 9025 \\
\hline Husband's years of education & 26244 & 9.02 & 4.93 & 0 & 30 \\
\hline Husband years of education sq. & 26244 & 105.72 & 86.81 & 0 & 900 \\
\hline \multicolumn{6}{|l|}{ Husband's employment position (base cat. No work) } \\
\hline Professional & 25913 & 0.25 & 0.43 & 0 & 1 \\
\hline Salesman & 25913 & 0.20 & 0.40 & 0 & 1 \\
\hline Self-employed in agriculture & 25913 & 0.05 & 0.23 & 0 & 1 \\
\hline Skilled blue collar & 25913 & 0.31 & 0.46 & 0 & 1 \\
\hline Unskilled blue collar & 25913 & 0.09 & 0.28 & 0 & 1 \\
\hline Other position & 25913 & 0.07 & 0.26 & 0 & 1 \\
\hline \multicolumn{6}{|l|}{ Geographic characteristics (base cat. South) } \\
\hline North & 26308 & 0.27 & 0.44 & 0 & 1 \\
\hline Central & 26308 & 0.13 & 0.34 & 0 & 1 \\
\hline East & 26308 & 0.12 & 0.33 & 0 & 1 \\
\hline Northeast & 26308 & 0.09 & 0.29 & 0 & 1 \\
\hline West & 26308 & 0.19 & 0.39 & 0 & 1 \\
\hline \multicolumn{6}{|l|}{ Programmes } \\
\hline Woman received a FP worker visit & 26307 & 0.09 & 0.29 & 0 & 1 \\
\hline
\end{tabular}

Data source: NFHS-2, 1998-99.

Note: North: Delhi, Haryana, Himachal Pradesh, Jammu \& Kashmir, Punjab, Rajasthan; Central: Madhya Pradesh, Uttar Pradesh; East: Bihar, Orissa, West Bengal; Northeast: Arunachal Pradesh, Assam, Manipur, Meghalaya, Mizoram, Negaland, Sikkim; West: Goa, Gujarat, Maharashtra; South: Andhra Pradesh, Karnataka, Kerala, Tamil Nadu. 
Table A3

Rural India summary statistics for the sub sample of married women aged 15-49

\begin{tabular}{|c|c|c|c|c|c|}
\hline Variables & Obs. & Mean & Std. Dev. & Min & Max \\
\hline \multicolumn{6}{|l|}{ Household's characteristics } \\
\hline Woman is the household head & 58510 & 0.02 & 0.14 & 0 & 1 \\
\hline Age of the household head & 58499 & 45.49 & 13.80 & 2 & 95 \\
\hline Household size & 58510 & 7.02 & 3.72 & 1 & 46 \\
\hline Wealth index & 58510 & -0.38 & 0.75 & -1.53 & 2.71 \\
\hline \multicolumn{6}{|l|}{ Children in the household } \\
\hline Own children aged 0-2 & 58177 & 0.38 & 0.56 & 0 & 4 \\
\hline Own children aged 3-5 & 58177 & 0.41 & 0.61 & 0 & 6 \\
\hline Own children aged 6-14 & 58177 & 1.09 & 1.24 & 0 & 7 \\
\hline Own children aged 15-17 & 58177 & 0.24 & 0.49 & 0 & 4 \\
\hline Other children in the family aged $0-2$ & 58177 & 0.21 & 0.54 & 0 & 6 \\
\hline Other children in the family aged 3-5 & 58177 & 0.18 & 0.53 & 0 & 7 \\
\hline Other children in the family aged 6-14 & 58177 & 0.43 & 1.03 & 0 & 16 \\
\hline Other children in the family aged $15-17$ & 58177 & 0.19 & 0.49 & 0 & 5 \\
\hline \multicolumn{6}{|l|}{ Woman's characteristics } \\
\hline Woman's age & 58510 & 30.48 & 8.72 & 15 & 49 \\
\hline Waman's age sq. & 58510 & 1005.11 & 559.70 & 225 & 2401 \\
\hline Womans's years of education & 58490 & 2.71 & 3.90 & 0 & 22 \\
\hline Womans's years of education sq. & 58490 & 22.54 & 42.08 & 0 & 484 \\
\hline Woman is Muslim & 58346 & 0.11 & 0.31 & 0 & 1 \\
\hline Woman is Christian & 58346 & 0.05 & 0.22 & 0 & 1 \\
\hline Woman is in a scheduled caste & 58006 & 0.18 & 0.39 & 0 & 1 \\
\hline Woman is in a scheduled tribe & 58006 & 0.14 & 0.35 & 0 & 1 \\
\hline Woman is currently working & 58499 & 0.39 & 0.49 & 0 & 1 \\
\hline Woman is currently working as paid worker & 23784 & 0.56 & 0.50 & 0 & 1 \\
\hline Women is currently working in a seasonal work & 23775 & 1.43 & 0.58 & 1 & 3 \\
\hline \multicolumn{6}{|l|}{ Husband 's characteristics } \\
\hline Husband's age & 58237 & 36.49 & 9.97 & 15 & 97 \\
\hline Husband's age sq. & 58237 & 1431.30 & 789.84 & 225 & 9409 \\
\hline Husband's years of education & 58405 & 5.49 & 4.75 & 0 & 30 \\
\hline Husband years of education sq. & 58405 & 52.62 & 62.95 & 0 & 900 \\
\hline \multicolumn{6}{|l|}{ Husband's employment position (base cat. No work) } \\
\hline Professional & 58024 & 0.08 & 0.28 & 0 & 1 \\
\hline Salesman & 58024 & 0.07 & 0.26 & 0 & 1 \\
\hline Self-employed in agriculture & 58024 & 0.50 & 0.50 & 0 & 1 \\
\hline Skilled blue collar & 58024 & 0.18 & 0.38 & 0 & 1 \\
\hline Unskilled blue collar & 58024 & 0.10 & 0.30 & 0 & 1 \\
\hline Other position & 58024 & 0.04 & 0.20 & 0 & 1 \\
\hline \multicolumn{6}{|l|}{ Geographic characteristics (base cat. South) } \\
\hline North & 58510 & 0.22 & 0.41 & 0 & 1 \\
\hline Central & 58510 & 0.21 & 0.40 & 0 & 1 \\
\hline East & 58510 & 0.20 & 0.40 & 0 & 1 \\
\hline Northeast & 58510 & 0.13 & 0.34 & 0 & 1 \\
\hline West & 58510 & 0.08 & 0.27 & 0 & 1 \\
\hline \multicolumn{6}{|l|}{ Prime age facilities } \\
\hline Primary school in the village & 58510 & 0.90 & 0.30 & 0 & 1 \\
\hline Anganwadi in the village & 58343 & 0.67 & 0.47 & 0 & 1 \\
\hline \multicolumn{6}{|l|}{ Family Planning } \\
\hline Woman received a FP worker visit (dummy) & 58509 & 0.12 & 0.32 & 0 & 1 \\
\hline FP worker visit in the village (dummy) & 58510 & 0.67 & 0.47 & 0 & 1 \\
\hline FP visit percentage of beneficiaries & 58510 & 2.16 & 2.87 & 0 & 22.86 \\
\hline
\end{tabular}




\begin{tabular}{|c|c|c|c|c|c|}
\hline IRDP (dummy) & 55822 & 0.60 & 0.49 & 0 & 1 \\
\hline NREP (dummy) & 56018 & 0.13 & 0.33 & 0 & 1 \\
\hline TRYSEM (dummy) & 56532 & 0.23 & 0.42 & 0 & 1 \\
\hline EGS (dummy) & 56273 & 0.09 & 0.29 & 0 & 1 \\
\hline DWACRA(dummy) & 56252 & 0.23 & 0.42 & 0 & 1 \\
\hline IAY (dummy) & 57040 & 0.64 & 0.48 & 0 & 1 \\
\hline SDNY (dummy) & 55800 & 0.09 & 0.29 & 0 & 1 \\
\hline IRDP percentage of beneficiaries in the village & 55822 & 0.92 & 1.95 & 0 & 48.00 \\
\hline NREP percentage of beneficiaries in the village & 56018 & 0.14 & 0.96 & 0 & 18.52 \\
\hline TRYSEM percentage of beneficiaries in the village & 56532 & 0.13 & 1.18 & 0 & 60.61 \\
\hline EGS percentage of beneficiaries in the village & 56273 & 0.13 & 1.46 & 0 & 75.76 \\
\hline DWACRA percentage of beneficiaries in the village & 56238 & 0.19 & 0.85 & 0 & 19.60 \\
\hline IAY percentage of beneficiaries in the village & 57040 & 0.52 & 1.92 & 0 & 90.91 \\
\hline SDNY percentage of beneficiaries in the village & 55786 & 0.10 & 0.97 & 0 & 100 \\
\hline
\end{tabular}




\section{Table A4}

MARGINAL EFFECTS OF THE PROBABILITY OF WORKING OF MARRIED WOMEN AGED 15-49- MULTINOMIAL LOGIT - All India

marginal effects*100 - standard errors in italics

\begin{tabular}{|c|c|c|c|}
\hline Household's characteristics & $\begin{array}{r}\text { Not } \\
\text { working } \\
\end{array}$ & $\begin{array}{r}\text { Working } \\
\text { unpaid } \\
\end{array}$ & $\begin{array}{r}\text { Working } \\
\text { paid } \\
\end{array}$ \\
\hline \multirow[t]{2}{*}{ Woman is the household head } & $-7.69^{\star \star \star}$ & $4.45^{\star \star \star}$ & $3.24^{\star \star \star}$ \\
\hline & -0.01 & 0.01 & 0.01 \\
\hline \multirow[t]{2}{*}{ Age of the household head } & $0.08^{\star \star \star}$ & $-0.02^{* * *}$ & $-0.06^{* \star \star}$ \\
\hline & 0.0002 & -0.0001 & -0.0001 \\
\hline \multirow[t]{2}{*}{ Household size } & $0.76^{\star \star \star}$ & $0.53^{\star \star \star}$ & $-1.29^{* \star \star}$ \\
\hline & 0.001 & 0.001 & -0.001 \\
\hline \multirow[t]{2}{*}{ Wealth index } & $9.36^{\star \star \star}$ & $-3.26^{\star \star \star}$ & $-6.10^{\star \star \star}$ \\
\hline & 0.003 & -0.002 & -0.003 \\
\hline \multicolumn{4}{|l|}{ Children in the household } \\
\hline \multirow[t]{2}{*}{ Own children aged 0-2 } & $6.14^{\star \star \star}$ & $-1.82^{* * *}$ & $-4.32^{\star * \star}$ \\
\hline & 0.004 & -0.002 & -0.003 \\
\hline \multirow[t]{2}{*}{ Own children aged 3-5 } & -0.34 & -0.21 & $0.55^{\star}$ \\
\hline & -0.003 & -0.002 & 0.003 \\
\hline \multirow[t]{2}{*}{ Own children aged 6-14 } & $-1.28^{\star \star \star}$ & $-0.27^{* * *}$ & $1.55^{\star \star \star}$ \\
\hline & -0.002 & -0.001 & 0.002 \\
\hline \multirow[t]{2}{*}{ Own children aged 15-17 } & $-1.02^{\star \star \star}$ & -0.13 & $1.15^{\star \star \star}$ \\
\hline & -0.004 & -0.002 & 0.003 \\
\hline \multirow[t]{2}{*}{ Other children in the family aged $0-2$} & -0.10 & $-0.40^{*}$ & 0.501 \\
\hline & -0.005 & -0.002 & 0.005 \\
\hline \multirow[t]{2}{*}{ Other children in the family aged 3-5 } & -0.10 & $-0.50^{* *}$ & 0.61 \\
\hline & -0.005 & -0.002 & 0.005 \\
\hline \multirow[t]{2}{*}{ Other children in the family aged 6-14 } & $-0.52^{*}$ & $-0.44^{* * *}$ & $0.96^{\star \star \star}$ \\
\hline & -0.003 & -0.001 & 0.003 \\
\hline \multirow[t]{2}{*}{ Other children in the family aged $15-17$} & -0.58 & 0.02 & 0.56 \\
\hline & -0.005 & 0.002 & 0.004 \\
\hline \multicolumn{4}{|l|}{ Woman's characteristics } \\
\hline \multirow[t]{2}{*}{ Woman's age } & $-2.01^{\star \star \star}$ & $0.38^{\star \star \star}$ & $1.62^{\star \star \star}$ \\
\hline & -0.002 & 0.001 & 0.002 \\
\hline \multirow[t]{2}{*}{ Waman's age sq. } & $0.02^{\star \star \star}$ & $-0.004^{\star \star \star}$ & $-0.02^{* \star \star}$ \\
\hline & 0.00003 & -0.00002 & -0.00003 \\
\hline \multirow[t]{2}{*}{ Womans's years of education } & $3.53^{\star \star \star}$ & $-0.55^{\star \star \star}$ & $-2.99^{\star \star \star}$ \\
\hline & 0.001 & -0.001 & -0.001 \\
\hline \multirow[t]{2}{*}{ Womans's years of education sq. } & $-0.29^{\star \star \star}$ & -0.06 & $0.30^{\star \star \star}$ \\
\hline & -0.0001 & -0.0001 & 0.0001 \\
\hline \multirow[t]{2}{*}{ Woman is Muslim } & $7.64^{\star \star \star}$ & $-1.49^{\star \star \star}$ & $-6.15^{\star \star \star}$ \\
\hline & 0.005 & -0.003 & -0.004 \\
\hline \multirow[t]{2}{*}{ Woman is Christian } & $-10.7^{\star \star \star}$ & $5.63^{\star \star \star}$ & $5.12^{\star \star \star}$ \\
\hline & 0.01 & 0.01 & 0.01 \\
\hline \multirow[t]{2}{*}{ Woman is in a scheduled caste } & $-4.54^{\star \star \star}$ & $-3.10^{\star \star \star}$ & $7.64^{\star \star \star}$ \\
\hline & -0.005 & -0.002 & 0.004 \\
\hline \multirow[t]{2}{*}{ Woman is in a scheduled tribe } & $-19.0^{\star \star \star}$ & $7.51^{\star \star \star}$ & $11.50^{\star \star \star}$ \\
\hline & -0.007 & -0.004 & 0.006 \\
\hline \multicolumn{4}{|l|}{ Husband 's characteristics } \\
\hline Husband's age & $-0.26^{*}$ & 0.05 & 0.21 \\
\hline & -0.002 & 0.001 & 0.001 \\
\hline Husband's age sq. & $0.004^{\star *}$ & -0.001 & $-0.003^{\star \star}$ \\
\hline & 0.00002 & -0.00001 & -0.00002 \\
\hline
\end{tabular}




\begin{tabular}{|c|c|c|c|}
\hline \multirow[t]{2}{*}{ Husband's years of education } & $1.32^{\star * *}$ & $0.191^{\star * *}$ & $-1.52^{\star \star \star}$ \\
\hline & 0.001 & 0.001 & -0.001 \\
\hline \multirow[t]{2}{*}{ Husband years of education sq. } & $-0.03^{\star * *}$ & $-0.008^{*}$ & $0.04^{\star * \star}$ \\
\hline & -0.00008 & -0.00005 & 0.00007 \\
\hline \multicolumn{4}{|c|}{ Husband's employment position (base cat. No work) } \\
\hline \multirow[t]{2}{*}{ Professional } & 1.75 & $1.93^{* *}$ & $-3.68 * \star \star$ \\
\hline & 0.01 & 0.01 & -0.01 \\
\hline \multirow[t]{2}{*}{ Salesman } & $5.88^{\star * *}$ & $2.77^{\star \star \star}$ & $-8.65^{\star \star \star}$ \\
\hline & 0.01 & 0.01 & -0.01 \\
\hline \multirow[t]{2}{*}{ Self-employed in agriculture } & $-2.62^{\star *}$ & $6.91^{\star \star \star}$ & $-4.29 * \star \star$ \\
\hline & -0.01 & 0.01 & -0.01 \\
\hline \multirow[t]{2}{*}{ Skilled blue collar } & $5.08^{* *}$ & 0.06 & $-5.14^{\star \star \star}$ \\
\hline & 0.01 & 0.01 & -0.01 \\
\hline \multirow[t]{2}{*}{ Unskilled blue collar } & $7.83^{\star * *}$ & $-3.30 * * *$ & $-4.53^{\star * *}$ \\
\hline & 0.009 & -0.005 & -0.008 \\
\hline \multirow[t]{2}{*}{ Other position } & $5.97^{\star * *}$ & 1.04 & $-7.01^{\star \star \star}$ \\
\hline & 0.01 & 0.01 & -0.01 \\
\hline \multicolumn{4}{|c|}{ Geographic characteristics (base cat. South) } \\
\hline \multirow[t]{2}{*}{ North } & $12.7^{\star * *}$ & $2.94^{\star \star \star}$ & $-15.6^{\star \star \star}$ \\
\hline & 0.005 & 0.003 & -0.003 \\
\hline \multirow[t]{2}{*}{ Central } & $12.4^{\star * *}$ & -0.42 & $-12.00^{* * *}$ \\
\hline & 0.005 & -0.003 & -0.003 \\
\hline \multirow[t]{2}{*}{ East } & $21.8^{\star * *}$ & $-7.72^{\star \star \star}$ & $-14.0^{* \star \star}$ \\
\hline & 0.004 & -0.002 & -0.003 \\
\hline \multirow[t]{2}{*}{ Northeast } & $15.2^{\star * \star}$ & $-3.86^{\star * \star}$ & $-11.40^{\star \star \star}$ \\
\hline & 0.004 & -0.003 & -0.003 \\
\hline \multirow[t]{2}{*}{ West } & $-4.72^{\star \star *}$ & $6.56^{\star \star \star}$ & $-1.84^{\star \star \star}$ \\
\hline & -0.007 & 0.005 & -0.005 \\
\hline \multirow[t]{2}{*}{ Urban area } & $4.13^{\star * *}$ & $-7.20^{\star * \star}$ & $3.07^{\star \star \star}$ \\
\hline & 0.005 & -0.002 & 0.004 \\
\hline \multicolumn{4}{|l|}{ Programmes } \\
\hline \multirow[t]{2}{*}{ Woman received a FP worker visit } & $-3.26^{\star * *}$ & $0.55^{*}$ & $2.72^{\star \star \star}$ \\
\hline & -0.006 & 0.003 & 0.005 \\
\hline Observations & & 82225 & \\
\hline \multicolumn{4}{|c|}{$\begin{array}{l}\text { Note: }{ }^{* *} p<0.01,{ }^{* *} p<0.05,{ }^{*} p<0.1 ;+: \text { dummy } \\
\text { Data source: NFHS-2, 1998-99 } \\
\text { Note: North: Delhi, Haryana, Himachal Pradesh, Jammu \& Kashmir, Punjab, } \\
\text { Rajasthan; Central: Madhya Pradesh, Uttar Pradesh; East: Bihar, Orissa, West } \\
\text { Bengal; Northeast: Arunachal Pradesh, Assam, Manipur, Meghalaya, Mizoram, } \\
\text { Negaland, Sikkim; West: Goa, Gujarat, Maharashtra; South: Andhra Pradesh, } \\
\text { Karnataka, Kerala, Tamil Nadu. }\end{array}$} \\
\hline
\end{tabular}




\section{MARGINAL EFFECTS OF THE PROBABILITY OF WORKING OF MARRIED WOMEN AGED 15-49 MULTINOMIAL LOGIT - Urban and Rural India}

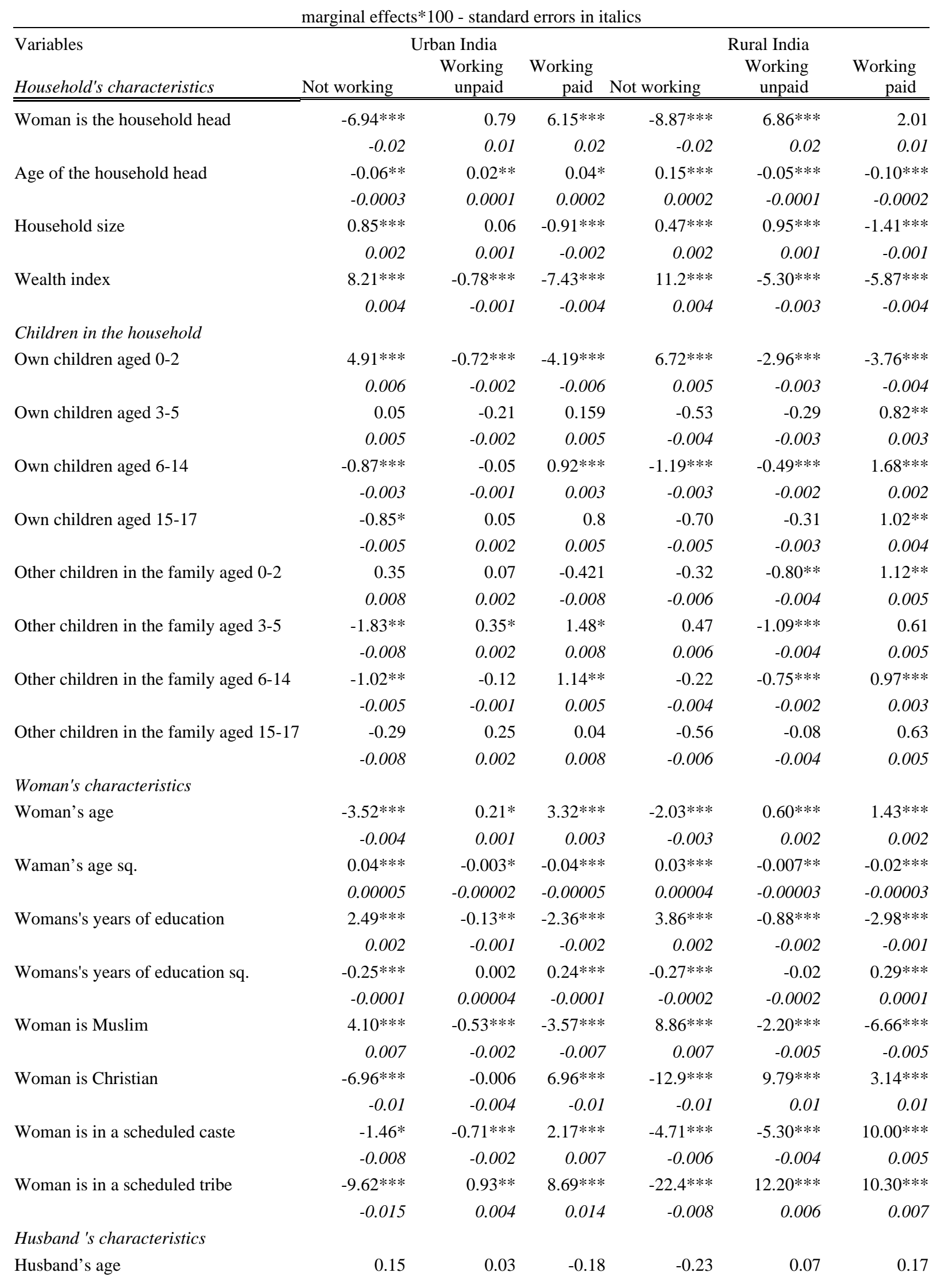




\begin{tabular}{|c|c|c|c|c|c|c|}
\hline & 0.003 & 0.001 & -0.003 & -0.002 & 0.001 & -0.002 \\
\hline \multirow[t]{2}{*}{ Husband's age sq. } & 0.001 & -0.0007 & -0.0004 & $0.004^{*}$ & -0.001 & -0.002 \\
\hline & 0.00003 & -0.00001 & -0.00003 & 0.00002 & -0.00002 & -0.00002 \\
\hline \multirow[t]{2}{*}{ Husband's years of education } & $0.86^{* * *}$ & 0.02 & $-0.87 * * *$ & $1.33 * * *$ & $0.31 * * *$ & $-1.64 * * *$ \\
\hline & 0.002 & 0.001 & -0.002 & 0.001 & 0.001 & -0.001 \\
\hline \multirow[t]{2}{*}{ Husband years of education sq. } & -0.009 & -0.003 & 0.01 & $-0.042 * * *$ & -0.01 & $0.05 * * *$ \\
\hline & -0.00010 & -0.00004 & 0.00010 & 0.00011 & -0.00008 & 0.00009 \\
\hline \multicolumn{7}{|c|}{ Husband's employment position (base cat. No work) } \\
\hline \multirow[t]{2}{*}{ Professional } & $3.64 * * *$ & -0.17 & $-3.47 * * *$ & -0.53 & $4.55^{* * *}$ & $-4.02 * * *$ \\
\hline & 0.01 & -0.01 & -0.01 & -0.02 & 0.02 & -0.01 \\
\hline \multirow[t]{2}{*}{ Salesman } & $7.10^{* * *}$ & $1.36^{*}$ & $-8.46 * * *$ & $5.20 * * *$ & $3.16^{* *}$ & $-8.36 * * *$ \\
\hline & 0.01 & 0.01 & -0.01 & -0.02 & 0.02 & -0.01 \\
\hline \multirow[t]{2}{*}{ Self-employed in agriculture } & -2.88 & $6.98 * * *$ & $-4.10 * * *$ & $-4.74 * * *$ & $9.84 * * *$ & $-5.10 * * *$ \\
\hline & -0.02 & 0.02 & -0.01 & -0.01 & 0.01 & -0.01 \\
\hline \multirow[t]{2}{*}{ Skilled blue collar } & $6.00^{* * *}$ & -0.07 & $-5.93 * * *$ & $3.59 * *$ & 0.27 & $-3.85 * * *$ \\
\hline & 0.01 & 0.005 & -0.01 & -0.02 & 0.01 & -0.01 \\
\hline \multirow[t]{2}{*}{ Unskilled blue collar } & $4.01^{* * *}$ & -0.33 & $-3.68 * * *$ & $9.63^{* * *}$ & $-6.18^{* * *}$ & $-3.45^{* * *}$ \\
\hline & 0.013 & -0.005 & -0.012 & -0.013 & -0.009 & -0.010 \\
\hline \multirow[t]{2}{*}{ Other position } & $6.09 * * *$ & -0.54 & $-5.55 * * *$ & $4.35^{* *}$ & $2.95 *$ & $-7.30 * * *$ \\
\hline & 0.01 & 0.00 & -0.01 & -0.02 & 0.02 & -0.01 \\
\hline \multicolumn{7}{|c|}{ Geographic characteristics (base cat. South) } \\
\hline \multirow[t]{2}{*}{ North } & $2.83^{* * *}$ & 0.28 & $-3.11 * * *$ & $16.80 * * *$ & $3.71 * * *$ & $-20.50 * * *$ \\
\hline & 0.007 & 0.003 & -0.007 & -0.007 & 0.006 & -0.003 \\
\hline \multirow[t]{2}{*}{ Central } & $5.18^{* * *}$ & -0.33 & $-4.85 * * *$ & $16.30 * * *$ & $-1.50 * * *$ & $-14.80 * * *$ \\
\hline & 0.008 & -0.003 & -0.007 & -0.006 & -0.005 & -0.004 \\
\hline \multirow[t]{2}{*}{ East } & $10.20 * * *$ & $-1.52 * * *$ & $-8.66 * * *$ & $29.90 * * *$ & $-14.20 * * *$ & $-15.70 * * *$ \\
\hline & 0.006 & -0.002 & -0.006 & -0.005 & -0.003 & -0.003 \\
\hline \multirow[t]{2}{*}{ Northeast } & $2.05 * *$ & -0.15 & $-1.89 * *$ & $21.80 * * *$ & $-7.89 * * *$ & $-13.90 * * *$ \\
\hline & 0.009 & -0.003 & -0.009 & -0.006 & -0.004 & -0.004 \\
\hline \multirow[t]{2}{*}{ West } & -0.38 & $0.89 * * *$ & -0.52 & $-13.30 * * *$ & $13.10^{* * *}$ & 0.21 \\
\hline & -0.008 & 0.003 & -0.007 & -0.010 & 0.009 & -0.006 \\
\hline \multicolumn{7}{|l|}{ Programmes } \\
\hline \multirow[t]{2}{*}{ Woman received a FP worker visit } & -1.31 & $0.56 *$ & 0.75 & $-2.42 * * *$ & 0.53 & $1.89 * * *$ \\
\hline & -0.009 & 0.003 & 0.009 & -0.007 & -0.005 & 0.005 \\
\hline Observations & & 5528 & & & 56697 & \\
\hline \multicolumn{7}{|c|}{$\begin{array}{l}\text { Note: North: Delhi, Haryana, Himachal Pradesh, Jammu \& Kashmir, Punjab, Rajasthan; Central: Madhya Pradesh, Uttar } \\
\text { Pradesh; East: Bihar, Orissa, West Bengal; Northeast: Arunachal Pradesh, Assam, Manipur, Meghalaya, Mizoram, Negaland, } \\
\text { Sikkim; West: Goa, Gujarat, Maharashtra; South: Andhra Pradesh, Karnataka, Kerala, Tamil Nadu. }\end{array}$} \\
\hline
\end{tabular}


Table A6

MARGINAL EFFECTS OF THE PROBABILITY OF WORKING OF MARRIED WOMEN AGED 15-49 COMPARING THE EFFECTS OF FP VISIT WITH GP - MULTINOMIAL LOGIT Rural India

marginal effects*100 - standard errors in italics

\begin{tabular}{|c|c|c|c|c|c|c|}
\hline \multirow{2}{*}{$\begin{array}{l}\text { Type of FP and GP var.: } \\
\text { Variables }\end{array}$} & \multicolumn{3}{|c|}{ Dummies } & \multicolumn{3}{|c|}{ Beneficiaries (\% of village population) } \\
\hline & $\begin{array}{l}\text { Not } \\
\text { working } \\
\end{array}$ & $\begin{array}{l}\text { Working } \\
\text { unpaid }\end{array}$ & $\begin{array}{l}\text { Working } \\
\text { paid }\end{array}$ & Not working & $\begin{array}{l}\text { Working } \\
\text { unpaid }\end{array}$ & $\begin{array}{l}\text { Working } \\
\text { paid }\end{array}$ \\
\hline \multirow[t]{2}{*}{ Woman is the household head } & $-9.36 * * *$ & $7.39 * * *$ & 1.97 & $-9.83^{* * *}$ & $7.98 * * *$ & 1.85 \\
\hline & -0.02 & 0.02 & 0.01 & -0.02 & 0.02 & 0.01 \\
\hline \multirow[t]{2}{*}{ Age of the household head } & $0.13^{* * *}$ & $-0.04 * *$ & $-0.08 * * *$ & $0.12 * * *$ & $-0.04 * * *$ & $-0.08 * * *$ \\
\hline & 0.0002 & -0.0002 & -0.0002 & 0.0002 & -0.0002 & -0.0002 \\
\hline \multirow[t]{2}{*}{ Household size } & $0.48^{* * *}$ & $0.95 * * *$ & $-1.43^{* * *}$ & $0.48^{* * *}$ & $0.96 * * *$ & $-1.44 * * *$ \\
\hline & 0.002 & 0.001 & -0.001 & 0.002 & 0.001 & -0.001 \\
\hline \multirow[t]{2}{*}{ Wealth index } & $11.10 * * *$ & $-5.25 * * *$ & $-5.87 * * *$ & $11.10 * * *$ & $-5.12 * * *$ & $-5.94 * * *$ \\
\hline & 0.005 & -0.003 & -0.004 & 0.005 & -0.003 & -0.004 \\
\hline \multicolumn{7}{|l|}{ Children in the household } \\
\hline \multirow[t]{2}{*}{ Own children aged 0-2 } & $6.43^{* * *}$ & $-2.96 * * *$ & $-3.48 * * *$ & $6.43^{* * *}$ & $-2.94 * * *$ & $-3.49 * * *$ \\
\hline & 0.005 & -0.004 & -0.004 & 0.005 & -0.004 & -0.004 \\
\hline \multirow[t]{2}{*}{ Own children aged 3-5 } & $-0.82 *$ & -0.299 & $1.11^{* * *}$ & $-0.84 *$ & -0.28 & $1.12 * * *$ \\
\hline & -0.004 & -0.003 & 0.004 & -0.004 & -0.003 & 0.004 \\
\hline \multirow[t]{2}{*}{ Own children aged 6-14 } & $-1.35 * * *$ & $-0.42 * *$ & $1.77 * * *$ & $-1.37 * * *$ & $-0.39 * *$ & $1.76^{* * *}$ \\
\hline & -0.003 & -0.002 & 0.002 & -0.003 & -0.002 & 0.002 \\
\hline \multirow[t]{2}{*}{ Own children aged 15-17 } & -0.80 & -0.21 & $1.01^{* *}$ & -0.85 & -0.16 & $1.01 * *$ \\
\hline & -0.005 & -0.004 & 0.004 & -0.005 & -0.004 & 0.004 \\
\hline \multirow[t]{2}{*}{ Other children in the family aged $0-2$} & -0.09 & $-0.88 * *$ & $0.97 *$ & 0.02 & $-0.96 * *$ & $0.94 *$ \\
\hline & -0.006 & -0.004 & 0.006 & 0.006 & -0.004 & 0.006 \\
\hline \multirow[t]{2}{*}{ Other children in the family aged 3-5 } & 0.33 & $-1.01^{* *}$ & 0.67 & 0.46 & $-1.13^{* * *}$ & 0.67 \\
\hline & 0.006 & -0.004 & 0.006 & 0.006 & -0.004 & 0.006 \\
\hline \multirow[t]{2}{*}{ Other children in the family aged 6-14 } & -0.17 & $-0.70 * * *$ & $0.86 * * *$ & -0.22 & $-0.68 * * *$ & $0.90 * * *$ \\
\hline & -0.004 & -0.003 & 0.003 & -0.004 & -0.003 & 0.003 \\
\hline \multirow[t]{2}{*}{ Other children in the family aged $15-17$} & -0.42 & -0.19 & 0.62 & -0.42 & -0.24 & 0.65 \\
\hline & -0.006 & -0.004 & 0.005 & -0.006 & -0.004 & 0.005 \\
\hline \multicolumn{7}{|l|}{ Woman's characteristics } \\
\hline \multirow[t]{2}{*}{ Woman’s age } & $-2.10 * * *$ & $0.63 * * *$ & $1.47 * * *$ & $-2.07 * * *$ & $0.59 * * *$ & $1.48 * * *$ \\
\hline & -0.003 & 0.002 & 0.002 & -0.003 & 0.002 & 0.002 \\
\hline \multirow[t]{2}{*}{ Waman's age sq. } & $0.03 * * *$ & $-0.007 * *$ & $-0.02 * * *$ & $0.03 * * *$ & $-0.006 * *$ & $-0.02 * * *$ \\
\hline & 0.00004 & -0.00003 & -0.00003 & 0.00004 & -0.00003 & -0.00003 \\
\hline \multirow[t]{2}{*}{ Womans's years of education } & $3.81^{* * *}$ & $-0.75 * * *$ & $-3.06 * * *$ & $3.87 * * *$ & $-0.80 * * *$ & $-3.07 * * *$ \\
\hline & 0.002 & -0.002 & -0.002 & 0.002 & -0.002 & -0.002 \\
\hline \multirow[t]{2}{*}{ Womans's years of education sq. } & $-0.27 * * *$ & $-0.04 * *$ & $0.31 * * *$ & $-0.28 * * *$ & $-0.03^{*}$ & $0.31 * * *$ \\
\hline & -0.0002 & -0.0002 & 0.0001 & -0.0002 & -0.0002 & 0.0001 \\
\hline \multirow[t]{2}{*}{ Woman is Muslim } & $7.72 * * *$ & $-1.72 * * *$ & $-6.00 * * *$ & $7.57 * * *$ & $-1.50 * * *$ & $-6.08 * * *$ \\
\hline & 0.008 & -0.006 & -0.006 & 0.008 & -0.006 & -0.006 \\
\hline Woman is Christian & $-14.8 * * *$ & $10.80 * * *$ & $3.98 * * *$ & $-14.90 * * *$ & $10.80 * * *$ & $4.06^{* * *}$ \\
\hline & -0.01 & 0.01 & 0.01 & -0.01 & 0.01 & 0.01 \\
\hline Woman is in a scheduled caste & $-4.91 * * *$ & $-5.40 * * *$ & $10.30 * * *$ & $-4.69 * * *$ & $-5.45 * * *$ & $10.10^{* * *}$ \\
\hline & -0.007 & -0.004 & 0.006 & -0.007 & -0.004 & 0.006 \\
\hline Woman is in a scheduled tribe & $-21.70 * * *$ & $12.60 * * *$ & $9.13 * * *$ & $-20.70 * * *$ & $11.90 * * *$ & $8.81 * * *$ \\
\hline & -0.01 & 0.01 & 0.01 & -0.01 & 0.01 & 0.01 \\
\hline Husband 's characteristics & & & & & & \\
\hline Husband's age & -0.22 & 0.11 & 0.1 & -0.28 & 0.14 & 0.13 \\
\hline & -0.002 & 0.002 & 0.002 & -0.002 & 0.002 & 0.002 \\
\hline
\end{tabular}




\begin{tabular}{|c|c|c|c|c|c|c|}
\hline \multirow[t]{2}{*}{ Husband's age sq. } & $0.004^{*}$ & -0.002 & -0.002 & $0.004^{*}$ & -0.002 & -0.002 \\
\hline & 0.00002 & -0.00002 & -0.00002 & 0.00002 & -0.00002 & -0.00002 \\
\hline \multirow[t]{2}{*}{ Husband's years of education } & $1.31 * * *$ & $0.38 * * *$ & $-1.69 * * *$ & $1.35^{* * *}$ & $0.35 * * *$ & $-1.70 * * *$ \\
\hline & 0.002 & 0.001 & -0.001 & 0.002 & 0.001 & -0.001 \\
\hline \multirow[t]{2}{*}{ Husband years of education sq. } & $-0.04 * * *$ & $-0.02^{* *}$ & $0.06 * * *$ & $-0.04 * * *$ & $-0.02 *$ & $0.06 * * *$ \\
\hline & -0.0001 & -0.0001 & 0.0001 & -0.0001 & -0.0001 & 0.0001 \\
\hline \multicolumn{7}{|c|}{ Husband's employment position (base cat. No work) } \\
\hline \multirow[t]{2}{*}{ Professional } & -1.43 & $5.05^{* * *}$ & $-3.63 * * *$ & -1.39 & $5.07 * * *$ & $-3.68 * * *$ \\
\hline & -0.02 & 0.02 & -0.01 & -0.02 & 0.02 & -0.01 \\
\hline \multirow[t]{2}{*}{ Salesman } & $4.78 * * *$ & $3.18^{* *}$ & $-7.96 * * *$ & $4.92 * * *$ & $3.07 *$ & $-7.99 * * *$ \\
\hline & 0.02 & 0.02 & -0.01 & 0.02 & 0.02 & -0.01 \\
\hline \multirow[t]{2}{*}{ Self-employed in agriculture } & $-5.62 * * *$ & $10.50 * * *$ & $-4.90 * * *$ & $-5.50 * * *$ & $10.50 * * *$ & $-4.97 * * *$ \\
\hline & -0.02 & 0.01 & -0.01 & -0.02 & 0.01 & -0.01 \\
\hline \multirow[t]{2}{*}{ Skilled blue collar } & $3.07 *$ & 0.41 & $-3.48 * * *$ & $3.10 * *$ & 0.33 & $-3.42 * * *$ \\
\hline & 0.02 & 0.01 & -0.01 & 0.02 & 0.01 & -0.01 \\
\hline \multirow[t]{2}{*}{ Unskilled blue collar } & $9.65^{* * *}$ & $-6.29 * * *$ & $-3.35 * * *$ & $9.47 * * *$ & $-6.27 * * *$ & $-3.20 * * *$ \\
\hline & 0.01 & -0.01 & -0.01 & 0.01 & -0.01 & -0.01 \\
\hline \multirow[t]{2}{*}{ Other position } & $3.82 * *$ & $3.48^{* *}$ & $-7.30 * * *$ & $3.76^{* *}$ & $3.55^{* *}$ & $-7.31 * * *$ \\
\hline & 0.02 & 0.02 & -0.01 & 0.02 & 0.02 & -0.01 \\
\hline \multicolumn{7}{|c|}{ Geographic characteristics (base cat. South) } \\
\hline \multirow[t]{2}{*}{ North } & $17.4 * * *$ & $2.41 * * *$ & $-9.80 * * *$ & $13.10^{* * *}$ & $6.67 * * *$ & $-19.70 * * *$ \\
\hline & 0.008 & 0.006 & -0.004 & 0.008 & 0.007 & -0.004 \\
\hline \multirow[t]{2}{*}{ Central } & $16.9 * * *$ & $-2.99 * * *$ & $-13.90 * * *$ & $12.40 * * *$ & 0.74 & $-13.10 * * *$ \\
\hline & 0.007 & -0.006 & -0.004 & 0.008 & 0.006 & -0.004 \\
\hline \multirow[t]{2}{*}{ East } & $30.00 * * *$ & $-15.20 * * *$ & $-14.80 * * *$ & $27.50 * * *$ & $-13.10 * * *$ & $-14.40 * * *$ \\
\hline & 0.005 & -0.004 & -0.004 & 0.006 & -0.004 & -0.004 \\
\hline \multirow[t]{2}{*}{ Northeast } & $22.30 * * *$ & $-9.53 * * *$ & $-12.80 * * *$ & $19.40 * * *$ & $-6.87 * * *$ & $-12.50 * * *$ \\
\hline & 0.006 & -0.005 & -0.004 & -0.007 & -0.006 & -0.004 \\
\hline \multirow[t]{2}{*}{ West } & $-9.69 * * *$ & $10.90 * * *$ & $-1.23 *$ & $-9.77 * * *$ & $11.10^{* * *}$ & $-1.36^{* *}$ \\
\hline & -0.01 & 0.01 & -0.01 & -0.01 & 0.01 & -0.01 \\
\hline \multicolumn{7}{|l|}{ Prime age facilities } \\
\hline \multirow[t]{2}{*}{ Primary school in the village } & $-3.45 * * *$ & -0.24 & $3.69 * * *$ & $-3.67 * * *$ & -0.36 & $4.02 * * *$ \\
\hline & -0.007 & -0.006 & 0.005 & -0.007 & -0.006 & 0.005 \\
\hline Anganwadi in the village & $-2.47 * * *$ & $0.921^{* *}$ & $1.55^{* * *}$ & $-2.18 * * *$ & 0.4 & $1.78^{* * *}$ \\
\hline & -0.005 & 0.004 & -0.004 & -0.005 & 0.004 & -0.004 \\
\hline Family Planning & & & & & & \\
\hline FP worker visit in the village (dummy) & $-5.26 * * *$ & 0.38 & $4.88 * * *$ & & & \\
\hline & -0.005 & 0.004 & 0.004 & & & \\
\hline FP visit percentage of beneficiaries & & & & $-1.41 * * *$ & $0.74 * * *$ & $0.67 * * *$ \\
\hline & & & & -0.001 & 0.001 & 0.001 \\
\hline GP- Welfare and Labour Market Progra & nes & & & & & \\
\hline IRDP (dummy) & $1.30 * *$ & $-1.82 * * *$ & 0.52 & & & \\
\hline & 0.005 & -0.004 & 0.004 & & & \\
\hline NREP (dummy) & $4.37 * * *$ & $-3.09 * * *$ & $-1.27 * *$ & & & \\
\hline & 0.007 & -0.005 & -0.005 & & & \\
\hline TRYSEM (dummy) & $4.22 * * *$ & $-2.82 * * *$ & $-1.40 * * *$ & & & \\
\hline & 0.006 & -0.004 & -0.005 & & & \\
\hline EGS (dummy) & $-3.32 * * *$ & $2.26 * * *$ & 1.05 & & & \\
\hline & -0.009 & 0.007 & 0.007 & & & \\
\hline DWACRA(dummy) & -0.133 & -0.46 & 0.59 & & & \\
\hline & -0.006 & -0.004 & -0.005 & & & \\
\hline IAY (dummy) & -0.51 & 0.44 & 0.07 & & & \\
\hline & -0.005 & -0.004 & -0.004 & & & \\
\hline SDNY (dummy) & $-4.04 * * *$ & $1.58^{* *}$ & $2.47 * * *$ & & & \\
\hline & -0.010 & 0.007 & 0.007 & & & \\
\hline
\end{tabular}


IRDP percentage of beneficiaries in the village

NREP percentage of beneficiaries in the village

TRYSEM percentage of beneficiaries in the village

EGS percentage of beneficiaries in the village

DWACRA percentage of beneficiaries in the village

IAY percentage of beneficiaries in the village

SDNY percentage of beneficiaries in the village

Observations

$\begin{array}{rrr}0.69 * * * & -0.83 * * * & 0.14 \\ 0.001 & -0.001 & 0.001 \\ 0.58^{*} & -0.21 & -0.37 \\ 0.003 & -0.002 & -0.003 \\ 3.63 * * * & -1.60 * * * & -2.03 * * * \\ 0.006 & -0.004 & -0.005 \\ -1.87 * * * & 0.97 * * * & 0.90^{* * *} \\ -0.004 & 0.002 & 0.003 \\ -2.36 * * * & 1.47 * * * & 0.89 * * * \\ -0.004 & 0.003 & 0.003 \\ -0.37 & 0.05 & 0.31 * \\ -0.002 & 0.002 & 0.002 \\ -1.56 * * * & 0.58 * * & 0.98^{* * *} \\ -0.005 & 0.002 & 0.003 \\ & 51732 & \end{array}$

51746

Note: $* * * p<0.01, * * p<0.05, * p<0.1 ;+:$ dummy

Data source: NFHS-2, 1998-99

Note: North: Delhi, Haryana, Himachal Pradesh, Jammu \& Kashmir, Punjab, Rajasthan; Central: Madhya Pradesh, Uttar Pradesh; East: Bihar, Orissa, West Bengal; Northeast: Arunachal Pradesh, Assam, Manipur, Meghalaya, Mizoram, Negaland, Sikkim; West: Goa, Gujarat, Maharashtra; South: Andhra Pradesh, Karnataka, Kerala, Tamil Nadu. 